\title{
Assessment of the Physico-chemical Characteristics and Water Quality Analysis of Mariout Lake, Southern of Alexandria, Egypt
}

\section{Abdelfattah S Saad ${ }^{1}$, Magdy A Massoud', Ranya A Amer ${ }^{2,3}$ and Mohamed A Ghorab ${ }^{4 *}$}

${ }^{1}$ Pesticide Chemistry and Toxicology, Plant Protection Department, Faculty of Agriculture-Saba Basha, Alexandria University, Egypt ${ }^{2}$ Environment and Natural Materials Research Institute (ENMRI), City of Scientific Research and Technology Applications (SRTA City), Alexandria, Egypt ${ }^{3}$ Genetic Engineering and Biotechnology Research Institute, City for Scientific Research and Technology Applications, Alexandria, Egypt ${ }^{4}$ Environmental Toxicology Lab, Central Laboratories Unit, National Institute of Oceanography, and Fisheries (NIOF), Alexandria, Egypt

\begin{abstract}
The present study objectively conducted to analysis the physico-chemical parameters and water quality of Mariout Lake water may be changed by several factors in the last decades as a result of anthropogenic activities. the water samples were collected from five sampling stations during the (June to November 2014-2015). The range of physico-chemical parameters were observed Temperature $(15.1-32.6)^{\circ} \mathrm{C}$, Conductivity $(280-380) \mu \mathrm{mhos} /$ cum, Total Dissolved Solid (345 -388) mg/l, pH (7.16-8.6), $\mathrm{O}_{2}$ Sat 33.2-97.8\%, Free alkalinity (3.34-6.73) mg/l, Total alkalinity (120-265) mg/l, DO (2.14-5.63) mg/l, BOD (2.6-15.2) mg/l, COD (7.4-15.6) mg/l, Chloride (13.6-33.2) mg/l, Calcium hardness (81.8-146.4) mg/l, Total hardness (100-289) mg/l, Nitrate-nitrogen (7.4- 11.1) $\mu \mathrm{M}$, Ammonia (87.0234.7) $\mu \mathrm{M}, \mathrm{N} / \mathrm{P}$ ratio (13.4-32.7) $\mu \mathrm{M}$ and Silicate (14.6- 221.9) $\mu \mathrm{M}$ during the study. It was concluded that temperature, $\mathrm{pH}$, total alkalinity, dissolved oxygen. biological oxygen demand, chemical oxygen demand, calcium hardness beyond the prescribed limits of WHO. We found that two identified sources are the main origin of most pollutants in this Lake, namely: El-Kalaa drain and industrial activities in Alexandria City. From the data of water quality index (WQI) and other parameters indicates that site V, EL-Mex Bay is more polluted than the other sites (from El-Umum Drain, El-Umum outlet, El Kalaa and El-Mex Pump station). For the sake of this work it is better first to give a preface about the general characteristics of the whole Mariout Lake, and indicated for the quality of the aquatic ecosystem is of great interest to the entire world. Introduction of different waste products into estuaries and seas especially those in industrial and population centers has lead to significant increase in the level of contamination by different pollutants.
\end{abstract}

Keywords: Physico-chemical; Pollutants; Aquatic ecosystem; Sewage pollution

\section{Introduction}

Water is essential for life on earth without it, life is impossible. Water, due to its great solvent power, is constantly threatened to get polluted easily. The requirement of water in all forms of lives, from micro-organisms to man, is a serious problem today because all water resources have been reached to a point of crisis due to unplanned urbanization and industrialization [1]. Mariout Lake second main stem reservoir on the Mediterranean Sea located in Southern of Alexandria, Egypt.

Temperature is one of the most important factors in aquatic environment. In general, most of the biological and chemical processes occurring in natural water bodies are greatly dependent on temperature. Its measurements in natural water bodies are subjected to great variations due to several factors such as, the latitude, sun altitude, season, wind, depth of water, waves, gain or loss of heat in shallow waters close to the land, etc.

Salinity is one of the most important characteristic factors which affects the survival and distribution of aquatic biota. The effect of salinity may be direct by affecting the survival of fish or indirect by affecting the amount and type of plankton which constitutes the main food web of the early larval stage.

Hydrogen ion concentration $(\mathrm{pH})$ plays an important role in many of the life processes in the sea, living organisms are very dependent on, and sensitive to $\mathrm{pH}$. It is dependent on the interaction of numerous substances dissolved in water, photosynthetic activity of aquatic plants, respiration of aquatic organisms, decomposition of organic matter, precipitation and/or dissolution of $\mathrm{CO}_{2}$ components and oxidation reduction reactions.
The Alkalinity may be defined as the excess of anions weak acids in seawater. Alkalinity is a measure of the capacity of the substances dissolved in the bicarbonate and carbonate which are ions formed when carbon dioxide or carbonate rocks dissolve in water. In other words, alkalinity is expressed as the sum of equivalents of $\mathrm{HCO}_{3}^{-}$, $\mathrm{CO}_{3}^{-}$and $\mathrm{B}(\mathrm{OH})_{4}^{-}$ions. The importance of alkalinity lies in its role in $\mathrm{CO}_{2}$ chemistry, trace metal speciation, buffer capacity of water, as a tracer for studying mixing processes between different water masses and a useful additional variable to study hydrographical features. It is affected by several processes which are photosynthesis and respiration, nitrification, denitrification, sulfide oxidation, sulfide reduction, and $\mathrm{CaCO}_{3}$ dissolution.

Oxygen studies in natural water are very important since the dissolved oxygen is one of the most important limiting factors for the life of aquatic organisms. On the other hand, it is an important parameter in assessing the degree of pollution. Sewage pollution has been generally regarded as an organic pollution, adversely affecting fish and other aquatic life, principally through oxygen depletion. The discharge of sewage into the sea is an important factor that disturbs the

*Corresponding author: Mohamed Adel Ghorab, Environmental Toxicology Lab Central Laboratories Unit, National Institute of Oceanography, and Fisheries (NIOF) Alexandria, Egypt, Tel: +2038243136; E-mail: mghorabniof@gmail.com

Received October 20, 2016; Accepted December 21, 2016; Published January 02 , 2017

Citation: Saad AS, Massoud MA, Amer RA, Ghorab MA (2017) Assessment of the Physico-chemical Characteristics and Water Quality Analysis of Mariout Lake Southern of Alexandria, Egypt. J Environ Anal Toxicol 7: 421. doi: 10.4172/2161. 0525.1000421

Copyright: @ 2017 Saad AS, et al. This is an open-access article distributed under the terms of the Creative Commons Attribution License, which permits unrestricted use, distribution, and reproduction in any medium, provided the original author and source are credited. 
Citation: Saad AS, Massoud MA, Amer RA, Ghorab MA (2017) Assessment of the Physico-chemical Characteristics and Water Quality Analysis of Mariout Lake, Southern of Alexandria, Egypt. J Environ Anal Toxicol 7: 421. doi: 10.4172/2161-0525.1000421

Page 2 of 19

oxygen distribution in the sea, especially in protected areas near the outfalls Such as Alexandria Costal Zone.

Lake Mariout is a brackish water lake receiving its water from agricultural drains, which collect drainage water from the Delta region and flow by gravity to El-Umum Drain. El-Umum Drain, in turn, discharges to the south-west corner of the Lake's main basin, the basin of concern in this study.

The second drain is EI-Kalaa Drain which discharges at the southeast corner of the basin under study. In addition, Noubaria Canal is considered the fresh water source for the Lake, yet its water by the time it reaches the Lake is saline and polluted. Industrial waste effluents are also mixed with domestic effluents and are discharged into the north side of the Lake at Moharrem Bey, at Ghiet El Enab, and at Karmous. During Phase I, the East Treatment Plant, after primary treating 410 $\mathrm{ML} / \mathrm{D}$, will discharge its effluent into an agricultural drain leading to El- Kalaa Drain and finally into Lake Mariout. The West Treatment plant, after primary treatment of the combined domestic and industrial effluents, will discharge 175 MUD into the north-west corner of the Lake. According to the Alexandria Master Plan, the three-north sewage industrial outfalls will be diverted to the collection system, and their discharges will then flow to the West Treatment Plant (Image 1).

The lake site is about 3000 feddans, with a very shallow bottom reaching $150 \mathrm{~cm}$ at its deepest location and a depth of $50 \mathrm{~cm}$ at shore locations around the lake periphery. SG:srn I (COAD-LMS) The east side of the basin is presently being filled with solid wastes and garbage collected from the City. Solid waste leachate from this side is an added nonpoint source of pollution load to the Lake basin. Excessive weed growth around the periphery and on isolated small islands in the Lake hinders the process of natural reaeration in the basin. The excessive organic and toxic chemical loads reaching, the basin in addition to low natural reaeration rate, contribute severely to the lake's continuous anaerobic state. The lake water level is maintained at a relatively constant level by means of the EL-Mex pumping station where water is discharged through a dug canal to the Mediterranean Sea.
Lake Mariout used to be a highly productive fishing lake as well as a recreational lake for wild duck hunting. The lake was divided into four basins upon the construction of the highway connecting Alexandria with the dessert areas around it and with Cairo. As the area around the lake became more developed, the cleanest east basin, used as a fishery basin, was filled with garbage, and used as a garden. The eastern side of the main basin is in the process of also being filled with domestic and industrial solid wastes.

Industrial development has occupied a relatively wide stretch around the lake with various industrial activities dumping their untreated wastes directly into the Lake. Domestic and industrial wastes generated and collected in the sewer system in the eastern part of the Governorate are also discharged to the Lake without any treatment either. Domestic sewage, mixed with agricultural drainage water, find their way to the main basin of the Lake through Gheit El Enab and Karmous drains. At the farthest southwest corner of the main basin, petroleum companies discharge their cooling and processing water, which is laden of oils and petroleum derivatives (Figure 1).

\section{Materials and Methods}

\section{Study area}

Mariout Lake is one of the main fishing grounds of Alexandria located between longitude $29^{\circ} 47.1^{\prime}$ to $29^{\circ} 50.4^{\prime} \mathrm{E}$ and latitude $31^{\circ} 7.5^{\prime}$ to $31^{\circ} 9^{\prime} \mathrm{N}$ (Figure 1). It represents a shallow sheltered Estuary west of Alexandria, extends for about $15 \mathrm{~km}$ between El-Agamy headland to the west to the Western Harbor to the east and from the coast to a depth of about $30 \mathrm{~m}$. The Bay has a mean depth of $10 \mathrm{~m}$. Its surface area is about $19.4 \mathrm{~km}^{2}$ and its volume is $190.3 \times 10^{6} \mathrm{~m}^{3}$ and the rate of waste water added to the basin via El -Umoum drain is $2452.7 \times 10^{6} \mathrm{~m}^{3} / \mathrm{y}$ [2-9]. ElMex Bay is dominated by two types of currents. El Mex Bay is classified as (to $30 \mathrm{~cm}$ ) and coastal currents drive water masses eastward at an average velocity of 0.5 knots. The wave height on the inner shelf reaches 1.5-2 $\mathrm{m}$ in winter [10]. Seven stations are chosen within the Bay to cover the whole Bay specially area around industrial activities and 4 samples from the drains.

\section{POLLUTION REDUCTION MEASURES FOR ALEXANDRIA COASTAL ZONE}

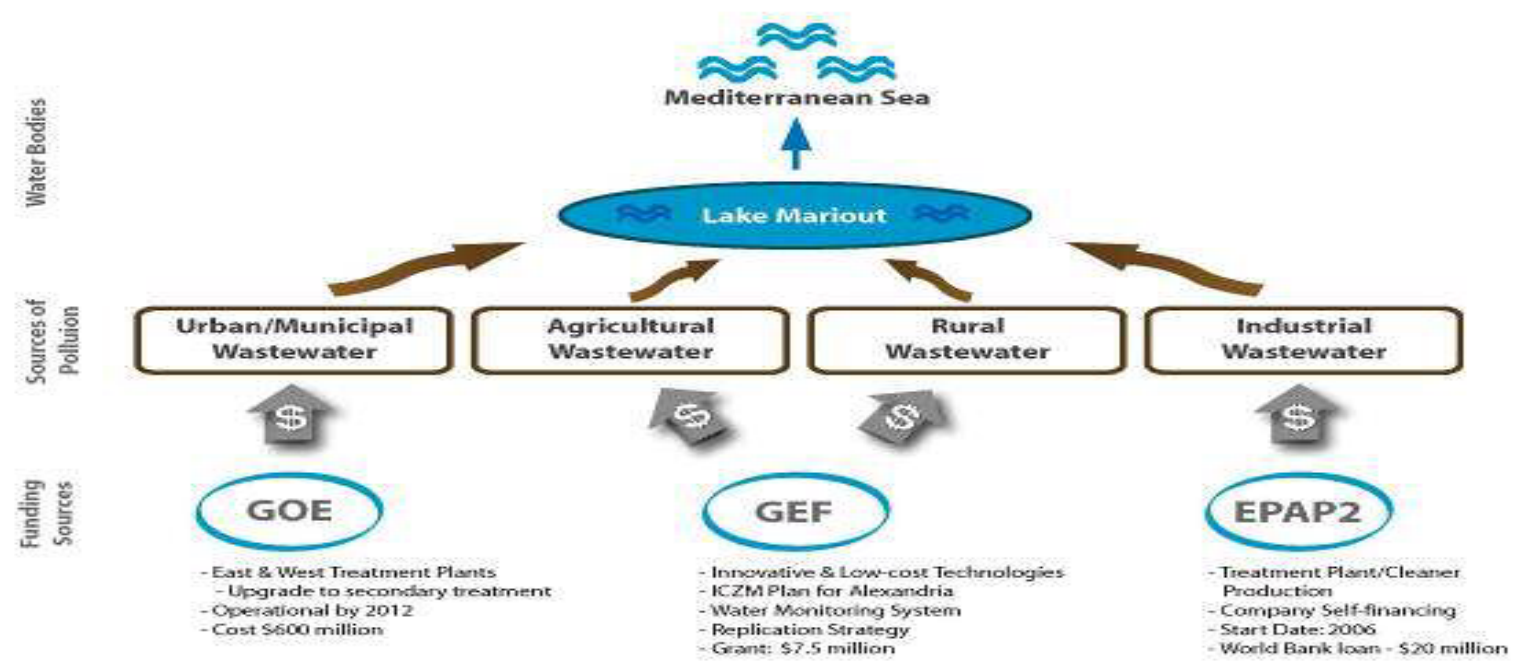

Image 1: Pollution Reduction Measures for Alexandria Coastal Zone. 
Citation: Saad AS, Massoud MA, Amer RA, Ghorab MA (2017) Assessment of the Physico-chemical Characteristics and Water Quality Analysis of Mariout Lake, Southern of Alexandria, Egypt. J Environ Anal Toxicol 7: 421. doi: 10.4172/2161-0525.1000421

Page 3 of 19

Physico-chemical measurements were done on the water samples collected seasonally during one year started from June 2014 to November 2015 at five locations representing an area subjected to the waste effluents. The water samples were collected to determine the following variables; salinity, $\mathrm{pH}$-value, total alkalinity, dissolved oxygen, oxidizable organic matter, major ions constituent $(\mathrm{Ca}, \mathrm{Mg}$, $\mathrm{Na}$ and $\mathrm{SO}_{4}$ ), nutrient salts (ammonia, nitrite, nitrate, phosphate and silicate).

Mariout area lies at the western part of Alexandria city (Figure 1). The area is subjected to industrial, agricultural and sewage wastes from different sources such as those wastes reaching Lake Mariout, its connected drains and in turn to El-Mex Bay. Industrial wastes from petroleum refineries, Chloro-alkali plant, cement, steel, and tanning industries discharge directly into the area without any pretreatment. Continuous increasing of pollution takes place at this area from these different sources.

Station I: El-Kalaa: The Lake is situated along the Mediterranean coast of Egypt south of Alexandria city. It is closed, having no connection with the sea. It has been divided artificially into four basins (the fish farm (F.F.), the north-western (N.W.), the south-western (S.W.) and the main basins). The main basin (M.B.) is the heavily polluted part of the Lake. It receives most of its water from a heavily polluted drain (Main Drain). Moreover, during February 2003, the remaining opened disposal sites to the beaches of Alexandria were locked and converted to the Lake Mariout [11].

Station II: El-Umum drain: The Drain carries mainly agricultural drainage water from El-Beheira Prefecture as well as mixed wastes from the Lake Mariout. This Drain has the largest outflow of all the west Delta drainage canals.
Station III: El-Mex pump station: El-Mex Pump station receives the surplus water from the Noubaria and other agricultural and disposes it to El-Mex Bay [11].

Station IV: El-Umum drain outlet: El-Umum Drain outlet is the location at which El-Umum Drain disposes its waste water to El-Mex Bay.

Station V: El-Mex bay: The Bay extends about $15 \mathrm{~km}$ between ElAgamy headland in the west and the Western Harbour in the east with a mean depth of $10 \mathrm{~m}$. It receives huge amounts of drainage water via El-Umum Drain as well as mixed wastes from Lake Maryout. The Bay is subjected to large temporal and spatial salinity fluctuations [12].

\section{Sampling}

Oxygen bottles of capacity $150 \mathrm{ml}$ were used to collect water samples for the determination of dissolved oxygen. Except for ammonia, filtrated samples for nutrient salts were collected in $500 \mathrm{ml}$ glass bottles from every site and the samples stored at $-20^{\circ} \mathrm{C}$. Well stoppered brown bottles of capacity $50 \mathrm{ml}$ were used for the fixation of ammonia in situ. Oxidizable organic matter was collected in brown bottles of capacity $100 \mathrm{ml}$. Water samples for heavy metals were collected in previously acid-washed polyethylene bottles $(2 \mathrm{~L})$.

\section{Methods of analysis}

Some parameters were totally or partially measured in field (i.e., as soon as the samples were collected).

Temperature $\left({ }^{\circ} \mathbf{C}\right)$ : Air and water temperatures were measured at the time of water sampling to the nearest $0.1^{\circ} \mathrm{C}$ by using ordinary thermometer.

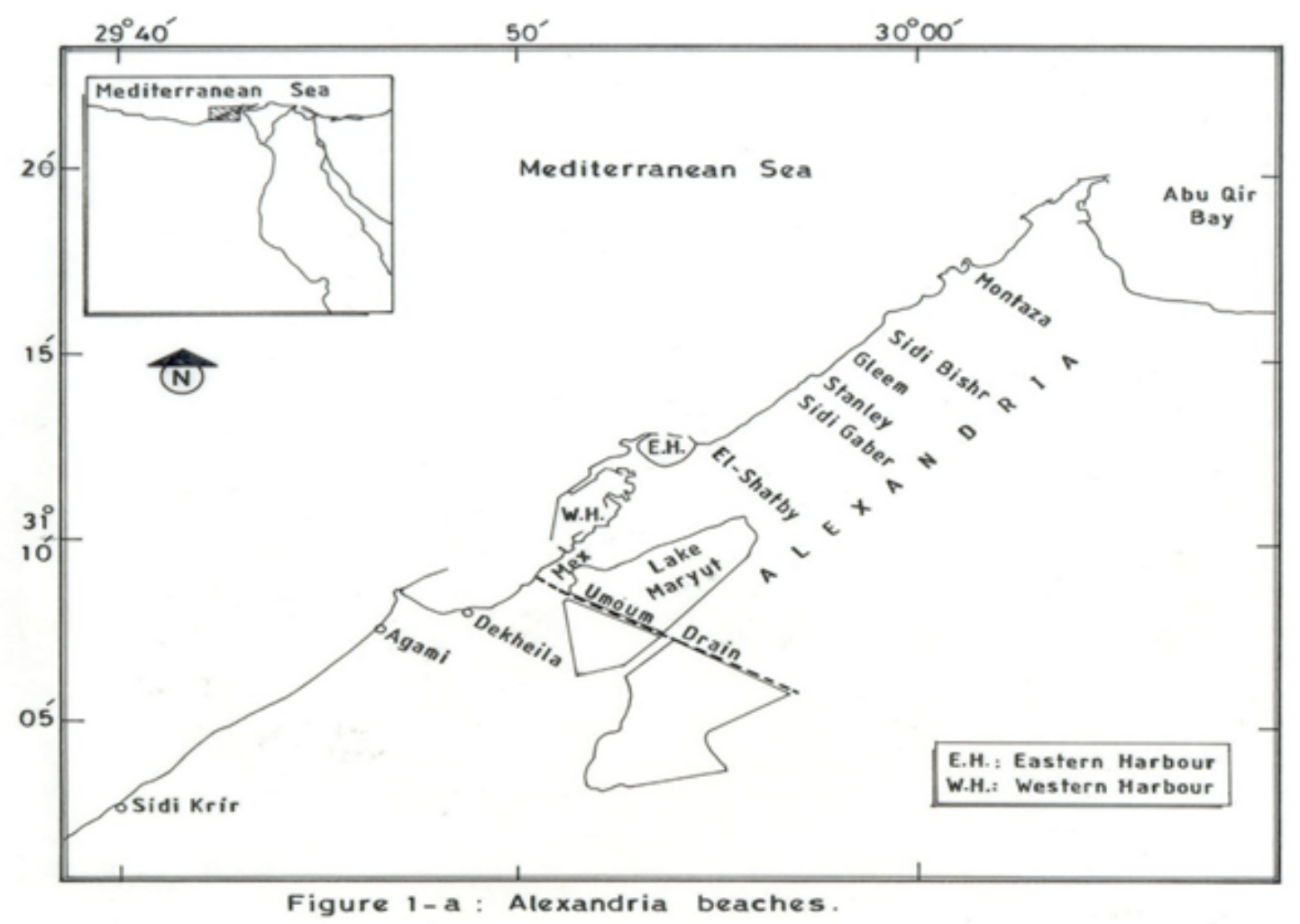

Figure 1: Mariout Lake area, sampling locations. 
Citation: Saad AS, Massoud MA, Amer RA, Ghorab MA (2017) Assessment of the Physico-chemical Characteristics and Water Quality Analysis of Mariout Lake, Southern of Alexandria, Egypt. J Environ Anal Toxicol 7: 421. doi: 10.4172/2161-0525.1000421

Page 4 of 19

Salinity (\%): Salinity was determined by measuring the electrical conductivity using an inductive salinometer (Beckman; model RS7C). The salinometer was standardized with standard seawater, Copenhagen, Denmark, of chlorinity $19.375 \%$. The conductivity was measured to the nearest 0.001 and converted to salinity up to the nearest $0.001 \%$ after making temperature correction using the international tables of salinity/conductivity conversion [12]. Chlorinity is computed according to the formula:

\section{$\mathrm{S} \%=1.80655 \mathrm{Cl} \%$}

The $\mathbf{p H}$-value: The $\mathrm{pH}$-value of water samples was measured in the laboratory immediately after collection using Bench type (JENWAY, 3410 Electrochemistry Analyzer $\mathrm{pH}$-meter) with reading up to $0.01 \mathrm{pH}$ unit after necessary precautions in the sampling and standardization processes [13].

Total alkalinity (meq/L): Alkalinity was measured according to the method mentioned in Strickland and Parsons [14]. Water sample was titrated against diluted $\mathrm{HCl}$ using methyl orange as indicator.

Dissolved oxygen (DO): The method described is the common Winkler method, modified by Carritt and Carpenter [15]. Fixation of dissolved oxygen was made in situ using manganous sulphate and alkaline potassium iodide solutions, taking all precautions that no bubbles are formed. After complete fixation of oxygen, the precipitated manganese hydroxide is allowed to settle and then dissolved by $9 \mathrm{~N}$ $\mathrm{H}_{2} \mathrm{SO}_{4}$. The liberated iodine was 12 .

Oxidizable organic matter (OOM): Since the carbon and hydrogen, but not nitrogen, in organic matter are oxidized by chemical oxidants, the oxygen consumed in these oxidations is sometimes erroneously considered as indicating the amount of carbonaceous organic matter present. The method used for the determination of oxidizable organic matter was described by FAO [16]. To a measured volume of sample, a known amount of the oxidant $\left(\mathrm{KMnO}_{4}\right)$ and sodium hydroxide is added; the sample is then heated in a boiling water bath. After 20 minutes, the oxidation is interrupted by cooling and the remaining amount of oxidant is, after acidification, determined iodometrically against thiosulphate solution. The amount of OOM is computed by

$$
\mathrm{mgO} / \mathrm{L}=8000[\mathrm{~N}(\mathrm{~B}-\mathrm{V})] / \mathrm{V}_{\mathrm{s}}
$$

$\mathrm{N}=$ Normality of sodium thiosulphate; $\mathrm{B}=$ Volume of sodium thiosulphate $(\mathrm{ml})$ recorded by blank; $\mathrm{V}=$ Volume of sodium thiosulphate $(\mathrm{ml})$ recorded by sample; $\mathrm{V}_{\mathrm{s}}=$ Volume of sample $(\mathrm{ml})$

\section{Major constituents}

Calcium $\left(\mathrm{Ca}^{+2}\right)$ : Calcium was measured titrimetrically against EDTA, according to the method mentioned in APHA [17]. Calcium was determined using murexide as indicator in alkaline medium.

Magnesium $\left(\mathbf{M g}^{+2}\right)$ : Total hardness $(\mathrm{Ca}$ and $\mathrm{Mg}$ ) was determined titrimetrically against EDTA using Eriochrome black-T as indicator and buffer solution to give $\mathrm{pH}$ of 10.0 , the color changes from pink to blue. Magnesium is estimated as a difference between total hardness and calcium value [18].

Sodium $\left(\mathrm{Na}^{+}\right)$: The sodium content of water samples was measured using Flame atomic absorption spectrophotometer (JENWAY, PFP 7).

Sulphate $\left(\mathrm{SO}_{4}^{-2}\right): \mathrm{SO}_{4}^{-2}$ is precipitated with $\mathrm{Ba}^{+2}$ in acidic medium using glycerol-ethanol solution as a conditional reagent. The sulphate is measured turbidimetric with spectrophotometer at wave length 420 $\mathrm{nm}$ [19]. Sulphate concentrations are obtained from the standard curve using different known concentrations.

\section{Nutrient salts}

For the determination of nutrient salts, water samples were filtered immediately using Millipore membrane filter. The dissolved inorganic nutrient salts were determined spectrophotometrically using a double beam spectrophotometer (Shimadzu visible-UV; model 150-02), according to the methods described by FAO [20]. The concentration values are expressed in $\mu \mathrm{M}$.

Ammonia $\left(\mathrm{NH}_{3} / \mathrm{N}\right)$ : The indophenol blue method is specific for ammonia. The ammonia is allowed to react with hypochlorite in slightly alkaline medium to form monochloramine which in presence of phenol nitroprusside ions and excess hypochlorite gives indophenol blue. The developed blue color is measured after 16-24 hours at 630 $\mathrm{nm}[21,22]$.

Nitrite $\left(\mathrm{NO}_{2} / \mathrm{N}\right)$ : The nitrite ion at $\mathrm{pH} 1.5-2.0$ is diazotized with sulphanilamide, resulting in a diazo compound, which in turn is coupled with $\mathrm{N}$-(1-naphthyl)-ethylenediamine to form a highly colored azo dye which is measured at $545 \mathrm{~nm}$.

Nitrate $\left(\mathrm{NO}_{3} / \mathrm{N}\right)$ : The method involves the reduction of nitrate to nitrite. The reduction took place in a heterogeneous system using cadmium granules and copper coated, the reduced samples were determined as nitrite. Nitrate was calculated by subtraction of the initial nitrite value from the total nitrite value (after the reduction step). The efficiency of cadmium column was checked periodically and it was almost between 94 and 96\% [23,24].

Dissolved inorganic phosphate $\left(\mathrm{PO}_{4} / \mathrm{P}\right)$ : The phosphate in water is allowed to react with ammonium molybdate, forming a complex heteropoly acid. This acid is reduced by ascorbic acid to a blue colored complex. The absorbance is measured at $880 \mathrm{~nm}$ [25].

Silicate $\left(\mathrm{SiO}_{3} / \mathrm{Si}\right)$ : The determination of dissolved silicon compound is based on the formation of a yellow silicomolybdic acid, when an acidic sample is treated with a molybdate reagent. The yellow color of silicomolybdic acid is reduced by ascorbic acid to form the blue silicomolybdic complex. The extinction of blue color is measured spectrophotometrically at $810 \mathrm{~nm}[26]$.

\section{Results and Discussion}

Water quality of Mariout Lake water may be changed by several factors in the last decades as a result of anthropogenic activities. So, it is important to study the physicochemical characteristics of water in the Mariout lake. The absolute as well as seasonal average values of different physico-chemical parameters; air and water temperatures, salinity, $\mathrm{pH}$-value, total alkalinity, dissolved oxygen, oxidizable organic matter, major constituents, nutrient salts as well as some heavy metals at El-Mex area during the year (2014-2015) were investigated [27].

\section{Temperature}

The absolute as well as the seasonal average values of air and surface water temperature at five sites during the period of study are given in Table 1 and illustrated in Figures 2-5. Air temperature averages varied from $22.7^{\circ} \mathrm{C}$ (winter) to $32.6^{\circ} \mathrm{C}$ (summer), with an annual average of $28.3^{\circ} \mathrm{C}$. The water temperature $\left({ }^{\circ} \mathrm{C}\right)$ attained its maximum value of $29.9^{\circ} \mathrm{C}$ in summer at El-Mex Bay station (V) and its minimum of $15.1^{\circ} \mathrm{C}$ in winter at El Kalaa Drain (I). The seasonal average temperatures were preceding also normal trend as expected; it increased from winter $\left(17.0^{\circ} \mathrm{C}\right)$ through spring $\left(25.9^{\circ} \mathrm{C}\right)$ reaching maximum level during summer $\left(29.0^{\circ} \mathrm{C}\right)$ and decrease again during autumn $\left(28.1^{\circ} \mathrm{C}\right)[28,29]$. 
Citation: Saad AS, Massoud MA, Amer RA, Ghorab MA (2017) Assessment of the Physico-chemical Characteristics and Water Quality Analysis of Mariout Lake, Southern of Alexandria, Egypt. J Environ Anal Toxicol 7: 421. doi: 10.4172/2161-0525.1000421

Page 5 of 19

\begin{tabular}{|c|c|c|c|c|c|c|c|c|c|c|}
\hline \multirow{2}{*}{ Stations } & \multicolumn{2}{|c|}{ Autumn } & \multicolumn{2}{c|}{ Winter } & \multicolumn{2}{c|}{ Spring } & \multicolumn{2}{c|}{ Summer } & \multicolumn{2}{c|}{ Annual average } \\
\cline { 2 - 11 } & Air & Water & Air & Water & Air & Water & Air & Water & Air & Water \\
\hline I & 31.0 & 27.0 & 21.5 & 15.1 & 27.0 & 26.5 & 30.1 & 28.9 & 27.4 & 24.4 \\
\hline II & 32.0 & 27.1 & 23.0 & 16.2 & 26.0 & 25.5 & 30.1 & 28.0 & 27.8 & 24.2 \\
\hline III & 31.0 & 29.5 & 21.1 & 18.3 & 28.0 & 26.0 & 37.1 & 29.1 & 29.3 & 25.7 \\
\hline IV & 30.0 & 28.0 & 24.9 & 16.8 & 26.5 & 26.0 & 33.0 & 29.3 & 28.6 & 25.0 \\
\hline V & 31.5 & 29.0 & 22.9 & 18.5 & 26.0 & 25.5 & 32.8 & 29.9 & 28.3 & 25.7 \\
\hline Seasonal average & 31.1 & 28.1 & 22.7 & 17.0 & 26.7 & 25.9 & 32.6 & 29.0 & 28.3 & 25.0 \\
\hline
\end{tabular}

Table 1: Seasonal variations of air and water temperatures $\left({ }^{\circ} \mathrm{C}\right)$ at El-Mex area during $(2014-2015)$.

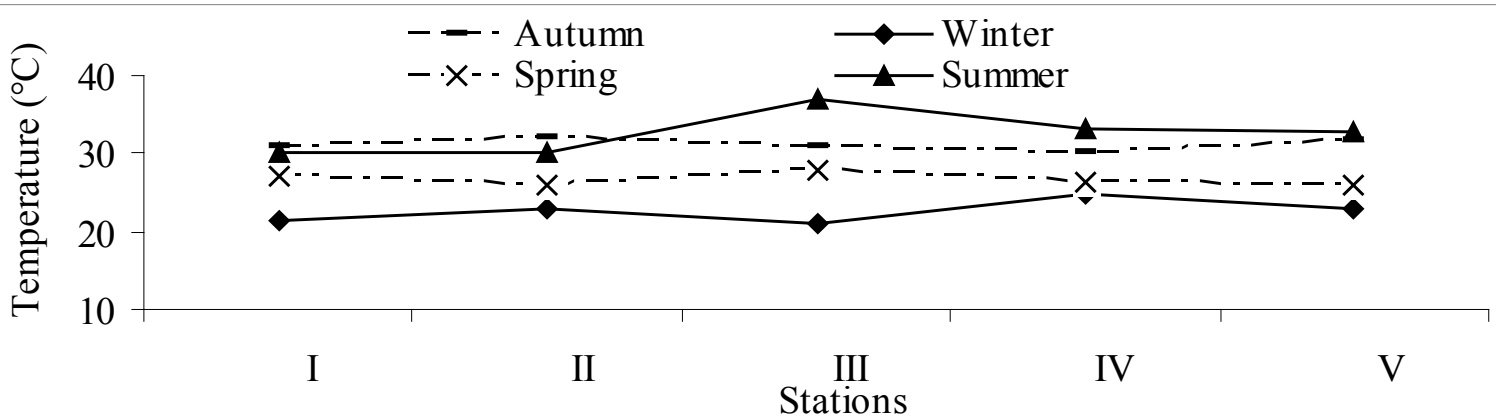

Figure 2: Seasonal air temperature $\left({ }^{\circ} \mathrm{C}\right)$ at studied sites during $(2014-2015)$

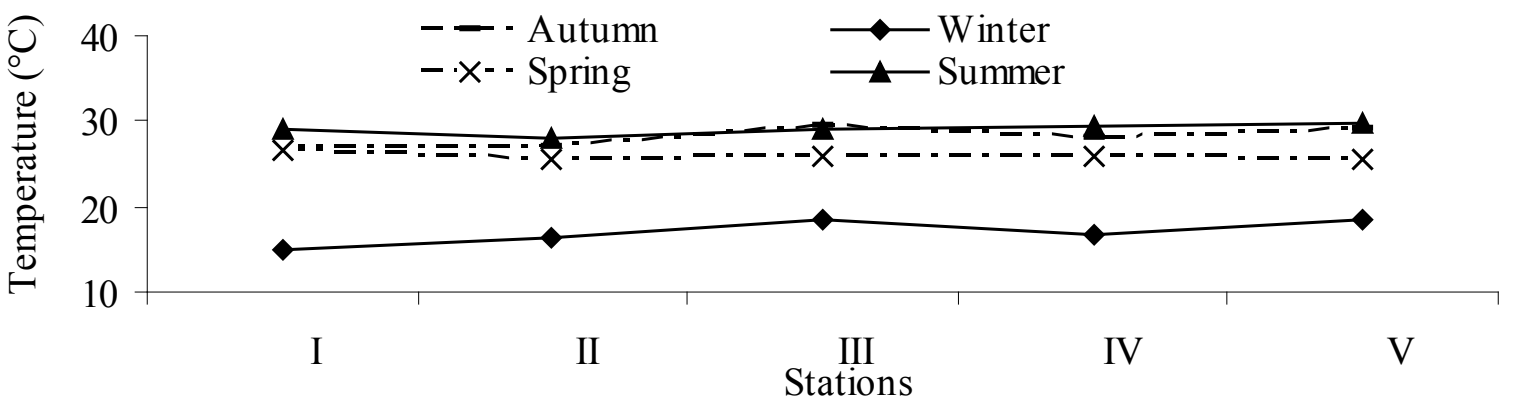

Figure 3: Seasonal water temperature $\left({ }^{\circ} \mathrm{C}\right)$ at studied sites during (2014-2015).

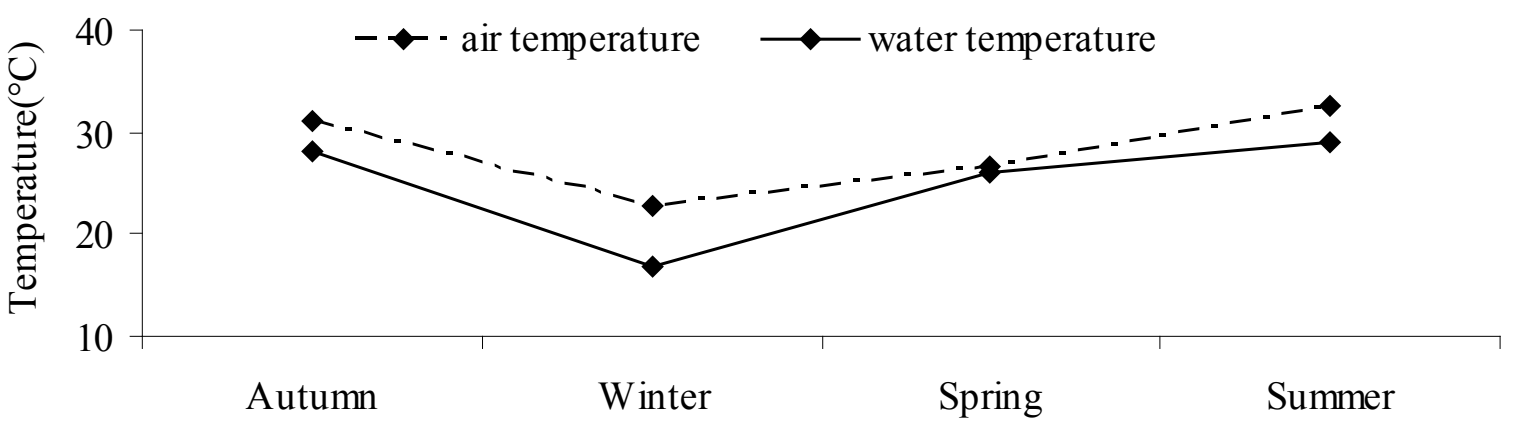

Figure 4: Seasonal air and water temperature averages $\left({ }^{\circ} \mathrm{C}\right)$ at studied sites during (2014-2015).

\section{Hydrographical parameters}

The different hydrographical parameters (salinity, pH-value, total alkalinity, dissolved oxygen and oxidizable organic matter) are represented in Table 2 .

Salinity: Salinity exhibited a wide range between seawater; El-Mex Bay station (V) and waste waters (Sts.I-IV); El Kalaa, El-Umum, Pump and El-Umum Drain outlet represented domestic, agricultural, and industrial waters.

Table 2 displays the seasonal and annual averages of salinity at different sites which are illustrated in Figures 6 and 7. The lowest salinity average of $4.678 \%$ was given during winter while summer represented the highest average of salinity $(6.436 \%)$ for waste water sites, with an annual average of $5.793 \%$. On the other hand, El-Mex 
Citation: Saad AS, Massoud MA, Amer RA, Ghorab MA (2017) Assessment of the Physico-chemical Characteristics and Water Quality Analysis of Mariout Lake, Southern of Alexandria, Egypt. J Environ Anal Toxicol 7: 421. doi: 10.4172/2161-0525.1000421

Page 6 of 19

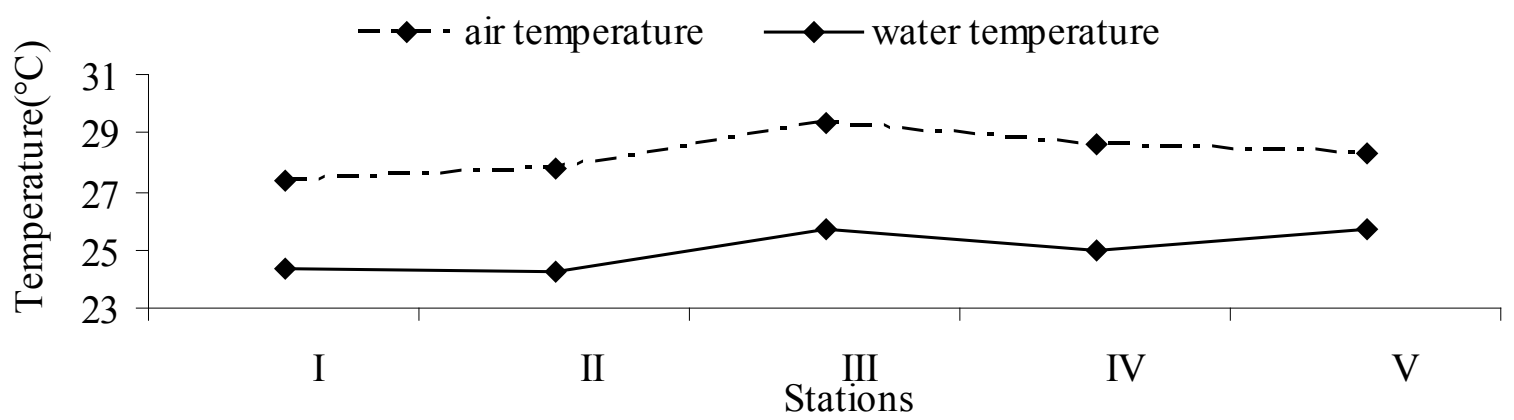

Figure 5: Annual air and water temperature averages $\left({ }^{\circ} \mathrm{C}\right)$ at studied sites during (2014-2015).

Bay station $(\mathrm{V})$ representing seawater indicates a reversible trend where the highest level was recorded during winter (37.055\%) and the lowest during spring (27.010\%), with an annual average of $32.296 \%$. Regionally, the salinity values showed noticeable local variations where the annual salinity averages increased seawards started with $4.762 \%$ at El Kalaa site (I) to $7.973 \%$ at El-Umum Drain outlet site (IV) reaching maximum level at El-Mex Bay (St.V) 32.296\% (Figure 7) [30-32].

The $\mathbf{p H}$ value: The $\mathrm{pH}$-values of surface water samples are given in Table 2 and illustrated in Figure 8. During the period of study, maximum readings of $\mathrm{pH}$-values at waste water stations were observed during summer at El Kalaa (8.25), El-Umum (8.60) and 8.35 at each of Pump and El-Umum Drain outlet stations while the lowest $\mathrm{pH}$-value of 7.10 was measured during spring at Pump station. The $\mathrm{pH}$-value of seawater station $(\mathrm{V})$ ranged between 7.70 during spring and 8.35 during winter. Most of data lies at alkaline side $(>7-<9)$. Waste waters show relative wide range of $\mathrm{pH}$ values $(7.10-8.60)$ if compared with saline water at St.V (7.70-8.35) [33].

Total alkalinity: The absolute as well as the average values of total alkalinity in meq/L are presented in Table 2 and illustrated in Figures 9 and 10 . Brackish waste water gave higher values of alkalinity which are more or less twice times that of seawater [34].

The seasonal waste water averages ranged from $5.425 \mathrm{meq} / \mathrm{L}$ during spring to $6.153 \mathrm{meq} / \mathrm{L}$ during winter, with an annual average of 5.797 $\mathrm{meq} / \mathrm{L}$. With respect to El-Mex Bay, the minimum total alkalinity of $2.905 \mathrm{meq} / \mathrm{L}$ was investigated during winter while summer season gave the maximum total alkalinity of $3.570 \mathrm{meq} / \mathrm{L}$, with an annual average of $3.343 \mathrm{meq} / \mathrm{L}$ [35]. The specific alkalinity values were reported in Table 2 and represented in Figure 11. The specific alkalinity of the waste water ranged between 0.962 at El-Umum Drain outlet (IV) during spring and 3.447 at Pump station (III) during winter, with an annual average of 1.980. With respect to seawater (St.V), the specific alkalinity fluctuated between 0.142 and 0.227 during winter and spring, respectively, with an annual average of 0.191 .

Dissolved oxygen: The surface distribution of $\mathrm{DO}\left(\mathrm{mlO}_{2} / \mathrm{L}\right)$ at different sites as well as the corresponding saturation percentages are given in Table 2 and illustrated in Figures 12-14.

The seasonal averages of dissolved oxygen at waste water stations (I-IV) attained its minimum value of $1.21 \mathrm{ml} / \mathrm{L}$ (Sat.17.7\%) during winter, tend to increase during spring, $2.48 \mathrm{ml} / \mathrm{L}$ (Sat.43.6\%) reaching a maximum value of $3.04 \mathrm{ml} / \mathrm{L}$ (Sat.56.1\%) during summer, with an annual average of $2.14 \mathrm{ml} / \mathrm{L}$. The seawater (St.V) fluctuated between a minimum of $4.89 \mathrm{ml} / \mathrm{L}$ (Sat.90.8\%) during autumn and a maximum of $7.37 \mathrm{ml} / \mathrm{L}$ (Sat.113.7\%) during winter, with an annual average of 5.63 $\mathrm{ml} / \mathrm{L}$ (Figure 12) [36].
Oxidizable organic matter: The values of OOM in the studied area are shown in Table 2 and illustrated in Figures 15 and 16. Significant seasonal variations of $\mathrm{OOM}$ occurred at waste water stations where the maximum average of $22.4 \mathrm{mgO} / \mathrm{L}$ and minimum of $10.7 \mathrm{mgO} / \mathrm{L}$ were observed during winter and summer, respectively, with an annual average of $15.6 \mathrm{mgO} / \mathrm{L}$. A relative narrow range in seasonal values at El-Mex Bay station was reported (10.0-5.2 $\mathrm{mgO} / \mathrm{L})$, with an annual average of $7.4 \mathrm{mgO} / \mathrm{L}$. Apart from seasonal changes, the values of OOM were more or less doubled apparently in waste water stations than in seawater station $[37,38]$.

\section{Major constituents}

Major ions concentration and their chlorinity ratios at studied sites during different seasons are shown in Table 3.

Calcium: The seasonal as well as annual values of calcium content are presented in Figures 17 and 18. The highest seasonal average of $\mathrm{Ca}^{+2}$ in waste water (Sts.I-IV) was estimated to be $146.4 \mathrm{mg} / \mathrm{L}$ during summer while the lowest was observed during spring being $81.8 \mathrm{mg} / \mathrm{L}$, with an annual average of $116.3 \mathrm{mg} / \mathrm{L}$. Obviously, calcium concentration at El Kalaa Drain was the lowest during both winter and spring seasons. Since it is reasonable to expect variations in major ions concentrations between seawater and waste waters stations, El-Mex Bay station contained more calcium than did waste water stations (about three folds) [39]. The maximum value of $391.7 \mathrm{mg} / \mathrm{L}$ was estimated during winter and a minimum of $253.5 \mathrm{mg} / \mathrm{L}$ during spring, with an annual average of $337.9 \mathrm{mg} / \mathrm{L}$.

The calcium/chlorinity ratio for waste water stations ranged from 0.0222 at El Kalaa Drain during spring to 0.0825 at Pump station during winter, with an annual average of 0.0384 which is too high if compared with normal oceanic ratio (0.0216) (Figure 19). El-Mex Bay station, however, shows negative declination below normal oceanic ratio $(0.0188$, on average), influenced by brackish water discharge.

Magnesium: The concentration of magnesium in seawater is about three times that of calcium. It was noticeable that magnesium content at waste water stations (Sts.I-IV) attained its maximum seasonal average during summer and its minimum during autumn being $155.8 \mathrm{mg} / \mathrm{L}$ and $96.3 \mathrm{mg} / \mathrm{L}$, respectively, with an annual average of $131.5 \mathrm{mg} / \mathrm{L}$. As in the case of calcium, magnesium content at El-Mex Bay station gave the highest value of $1397.8 \mathrm{mg} / \mathrm{L}$ during winter and the lowest value of $922.4 \mathrm{mg} / \mathrm{L}$ during spring, with an annual average of $1125.9 \mathrm{mg} / \mathrm{L}$ (Figures 20 and 21). Regionally, regular variations of annual averages occur among studied stations which appear to be increased gradually from El Kalaa Drain $(92.6 \mathrm{mg} / \mathrm{L})$ towards the sea $(1125.9 \mathrm{mg} / \mathrm{L})$. The magnesium/calcium ratio is fluctuated between 1:1 and 3:1 at waste and sea waters, respectively. With respect to magnesium/chlorinity 
Citation: Saad AS, Massoud MA, Amer RA, Ghorab MA (2017) Assessment of the Physico-chemical Characteristics and Water Quality Analysis of Mariout Lake, Southern of Alexandria, Egypt. J Environ Anal Toxicol 7: 421. doi: 10.4172/2161-0525.1000421

Page 7 of 19

\begin{tabular}{|c|c|c|c|c|c|c|c|c|}
\hline Seasons & Stations & Salinity (\%) & $\mathrm{pH}$ & Tot Alk (meq/L) & Spec. Alk. & $\mathrm{DO}(\mathrm{ml} / \mathrm{L})$ & $\mathrm{O}_{2}$ Sat. (\%) & OOM (mgO/L) \\
\hline \multirow{6}{*}{ 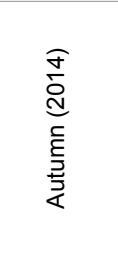 } & I & 5.013 & 7.16 & 5.858 & 2.111 & 2.33 & 41.8 & 9.2 \\
\hline & II & 4.854 & 7.17 & 5.719 & 2.129 & 2.38 & 42.7 & 23.6 \\
\hline & III & 5.204 & 7.30 & 5.043 & 1.751 & 0.85 & 16.1 & 22.0 \\
\hline & IV & 9.444 & 7.44 & 5.592 & 1.070 & 1.76 & 32.1 & 14.8 \\
\hline & $\begin{array}{c}\text { Seasonal average } \\
(\text { I-IV) }\end{array}$ & 6.129 & & 5.553 & 1.765 & 1.83 & 33.2 & 17.4 \\
\hline & $\mathrm{V}$ & 35.670 & 7.72 & 3.501 & 0.177 & 4.89 & 90.8 & 10.0 \\
\hline \multirow{6}{*}{ 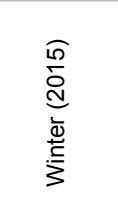 } & 1 & 4.285 & 7.70 & 7.482 & 3.155 & 0.00 & 0.0 & 38.4 \\
\hline & II & 5.236 & 8.07 & 5.722 & 1.974 & 2.39 & 34.7 & 4.8 \\
\hline & III & 2.860 & 7.58 & 5.458 & 3.447 & 1.37 & 20.3 & 23.6 \\
\hline & IV & 6.332 & 7.70 & 5.951 & 1.698 & 1.08 & 15.7 & 22.8 \\
\hline & Seasonal average (I-IV) & 4.678 & & 6.153 & 2.568 & 1.21 & 17.7 & 22.4 \\
\hline & $\mathrm{V}$ & 37.055 & 8.35 & 2.905 & 0.142 & 7.37 & 113.7 & 6.8 \\
\hline \multirow{6}{*}{ 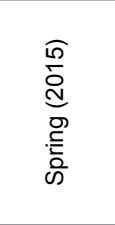 } & 1 & 4.128 & 7.65 & 7.210 & 3.155 & 0.00 & 0.0 & 27.6 \\
\hline & II & 5.013 & 7.70 & 5.040 & 1.816 & 4.45 & 78.4 & 4.4 \\
\hline & III & 5.976 & 7.10 & 4.865 & 1.471 & 2.39 & 42.1 & 6.8 \\
\hline & IV & 8.606 & 7.15 & 4.585 & 0.962 & 3.07 & 54.1 & 8.4 \\
\hline & Seasonal average (I-IV) & 5.931 & & 5.425 & 1.851 & 2.48 & 43.6 & 11.8 \\
\hline & $\mathrm{V}$ & 27.010 & 7.70 & 3.395 & 0.227 & 5.13 & 90.3 & 5.2 \\
\hline \multirow{6}{*}{ 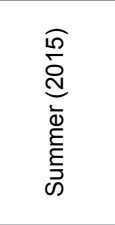 } & I & 5.623 & 8.25 & 6.372 & 2.047 & 3.41 & 63.3 & 9.6 \\
\hline & II & 5.623 & 8.60 & 6.069 & 1.950 & 4.67 & 85.2 & 7.2 \\
\hline & III & 6.985 & 8.35 & 5.891 & 1.523 & 2.16 & 40.1 & 12.8 \\
\hline & IV & 7.511 & 8.35 & 5.891 & 1.417 & 1.93 & 35.8 & 13.2 \\
\hline & Seasonal average (I-IV) & 6.436 & & 6.056 & 1.734 & 3.04 & 56.1 & 10.7 \\
\hline & $\mathrm{V}$ & 29.448 & 7.95 & 3.570 & 0.219 & 5.12 & 96.7 & 7.6 \\
\hline \multirow{6}{*}{$\begin{array}{l}0 \\
\frac{0}{\pi} \\
\frac{\pi}{0} \\
\frac{0}{0} \\
\frac{\pi}{T} \\
\frac{1}{5} \\
\frac{C}{4}\end{array}$} & 1 & 4.762 & & 6.731 & 2.617 & 1.44 & 26.3 & 21.2 \\
\hline & II & 5.182 & & 5.638 & 1.967 & 3.47 & 60.2 & 10.0 \\
\hline & III & 5.256 & & 5.314 & 2.048 & 1.69 & 29.6 & 16.3 \\
\hline & IV & 7.973 & & 5.505 & 1.287 & 1.96 & 34.4 & 14.8 \\
\hline & I-IV & 5.793 & & 5.797 & 1.980 & 2.14 & 37.6 & 15.6 \\
\hline & $\mathrm{V}$ & 32.296 & & 3.343 & 0.191 & 5.63 & 97.9 & 7.4 \\
\hline
\end{tabular}

Table 2: Seasonal variations of hydrographical parameters at El-Mex area during (2014-2015).

\begin{tabular}{|c|c|c|c|c|c|c|c|c|c|}
\hline \multirow{2}{*}{ Seasons } & \multirow{2}{*}{ Stations } & $\mathrm{Ca}^{+2}$ & \multirow{2}{*}{$\begin{array}{l}\mathrm{Ca}^{+2} \\
\mathrm{ICI}\end{array}$} & \multirow{2}{*}{$\begin{array}{l}\mathrm{Mg}^{+2} \\
\mathrm{mg} / \mathrm{L}\end{array}$} & \multirow{2}{*}{$\underset{/ \mathrm{Cl}}{\mathrm{Mg}^{+2}}$} & \multirow{2}{*}{$\begin{array}{c}\mathrm{Na}^{+} \\
\mathrm{mg} / \mathrm{L}\end{array}$} & \multirow{2}{*}{$\begin{array}{l}\mathrm{Na}^{+} \\
/ \mathrm{Cl}\end{array}$} & \multirow{2}{*}{$\begin{array}{l}\mathrm{SO}_{4}^{-2} \\
\mathrm{mg} / \mathrm{L}\end{array}$} & \multirow{2}{*}{$\mathrm{SO}_{4}^{-2}$} \\
\hline & & $\mathrm{mg} / \mathrm{L}$ & & & & & & & \\
\hline \multirow{6}{*}{ 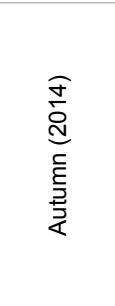 } & 1 & 113.9 & 0.0410 & 81.5 & 0.0294 & 441.4 & 0.159 & 668.0 & 0.241 \\
\hline & II & 116.1 & 0.0432 & 74.6 & 0.0278 & 252.9 & 0.094 & 648.0 & 0.241 \\
\hline & III & 113.9 & 0.0395 & 102.2 & 0.0355 & 436.8 & 0.152 & 708.0 & 0.246 \\
\hline & IV & 129.8 & 0.0248 & 127.0 & 0.0243 & 6161.2 & 1.179 & 762.0 & 0.146 \\
\hline & $\begin{array}{c}\text { o } \\
\text { average } \\
(\mathrm{I}-\mathrm{IV})\end{array}$ & 118.4 & 0.0371 & 96.3 & 0.0292 & 1823.1 & 0.396 & 696.5 & 0.218 \\
\hline & V & 382.6 & 0.0194 & 1052.3 & 0.0533 & 11600.2 & 0.588 & 2495.0 & 0.126 \\
\hline \multirow{6}{*}{ 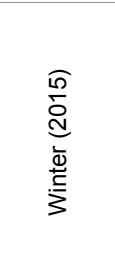 } & 1 & 69.8 & 0.0294 & 107.7 & 0.0454 & 183.9 & 0.078 & 168.0 & 0.071 \\
\hline & II & 124.5 & 0.0430 & 134.5 & 0.0464 & 390.8 & 0.135 & 644.0 & 0.222 \\
\hline & III & 130.6 & 0.0825 & 145.9 & 0.0921 & 597.7 & 0.378 & 579.0 & 0.366 \\
\hline & IV & 148.8 & 0.0424 & 164.8 & 0.0470 & 6598.0 & 1.882 & 807.0 & 0.230 \\
\hline & $\begin{array}{l}\text { Seasonal average } \\
(\text { IIIV) }\end{array}$ & 118.4 & 0.0493 & 138.2 & 0.0577 & 1942.6 & 0.618 & 549.5 & 0.222 \\
\hline & V & 391.7 & 0.0191 & 1397.8 & 0.0681 & 11816.7 & 0.576 & 2856.0 & 0.139 \\
\hline \multirow{6}{*}{ 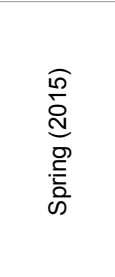 } & 1 & 50.7 & 0.0222 & 50.3 & 0.0220 & 183.9 & 0.080 & 69.0 & 0.030 \\
\hline & II & 78.4 & 0.0282 & 111.8 & 0.0403 & 528.8 & 0.191 & 243.0 & 0.088 \\
\hline & III & 87.6 & 0.0265 & 139.8 & 0.0422 & 689.7 & 0.208 & 282.0 & 0.085 \\
\hline & IV & 110.6 & 0.0232 & 240.4 & 0.0505 & 4712.9 & 0.989 & 455.0 & 0.096 \\
\hline & $\begin{array}{l}\text { Seasonal average } \\
(\text { I-IV) }\end{array}$ & 81.8 & 0.0250 & 135.6 & 0.0388 & 1528.8 & 0.367 & 262.3 & 0.075 \\
\hline & $\mathrm{V}$ & 253.5 & 0.0170 & 922.4 & 0.0617 & 11058.0 & 0.740 & 1678.0 & 0.112 \\
\hline
\end{tabular}


Citation: Saad AS, Massoud MA, Amer RA, Ghorab MA (2017) Assessment of the Physico-chemical Characteristics and Water Quality Analysis of Mariout Lake, Southern of Alexandria, Egypt. J Environ Anal Toxicol 7: 421. doi: 10.4172/2161-0525.1000421

Page 8 of 19

\begin{tabular}{|c|c|c|c|c|c|c|c|c|c|}
\hline \multirow{6}{*}{ 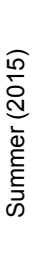 } & 1 & 149.0 & 0.0479 & 130.9 & 0.0420 & 320.2 & 0.103 & 881.0 & 0.283 \\
\hline & II & 159.3 & 0.0512 & 127.8 & 0.0410 & 320.1 & 0.103 & 921.0 & 0.296 \\
\hline & III & 133.6 & 0.0346 & 171.4 & 0.0443 & 612.3 & 0.158 & 866.0 & 0.224 \\
\hline & IV & 143.9 & 0.0346 & 193.2 & 0.0465 & 4305.6 & 1.036 & 683.0 & 0.164 \\
\hline & $\begin{array}{l}\text { Seasonal average } \\
(\text { I-IV) }\end{array}$ & 146.4 & 0.0421 & 155.8 & 0.0435 & 1389.6 & 0.350 & 837.8 & 0.242 \\
\hline & V & 323.7 & 0.0199 & 1131.1 & 0.0694 & 11265.0 & 0.691 & 2361.0 & 0.145 \\
\hline \multirow{6}{*}{ 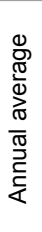 } & 1 & 95.9 & 0.0351 & 92.6 & 0.0347 & 282.4 & 0.105 & 446.5 & 0.156 \\
\hline & II & 119.6 & 0.0414 & 112.2 & 0.0389 & 373.2 & 0.131 & 614.0 & 0.212 \\
\hline & III & 116.4 & 0.0458 & 139.8 & 0.0535 & 584.1 & 0.224 & 608.8 & 0.230 \\
\hline & IV & 133.3 & 0.0313 & 181.4 & 0.0421 & 5444.4 & 1.271 & 676.8 & 0.159 \\
\hline & I-IV & 116.3 & 0.0384 & 131.5 & 0.0423 & 1671.0 & 0.433 & 586.5 & 0.189 \\
\hline & V & 337.9 & 0.0188 & 1125.9 & 0.0631 & 11435.0 & 0.649 & 2347.5 & 0.131 \\
\hline
\end{tabular}

Table 3: Major ions concentration and their chlorinity ratios at El-Mex area during (2014-2015).

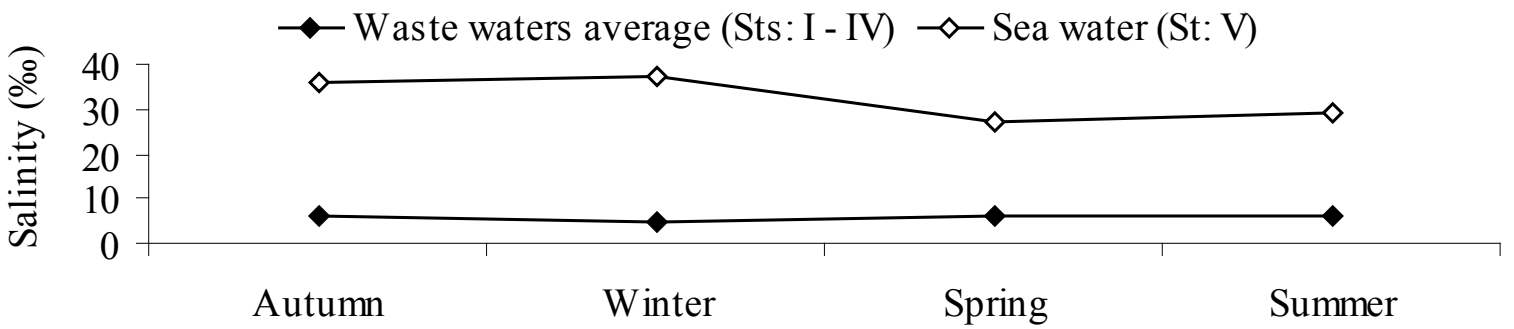

Figure 6: Seasonal salinity averages of waste water sites and seawater (2014-2015)

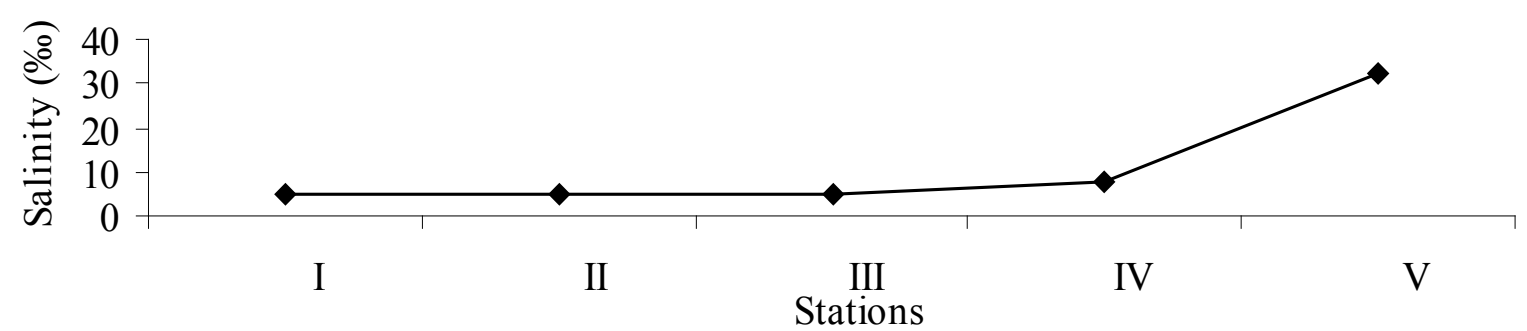

Figure 7: Annual salinity averages at studied sites (2014-2015)

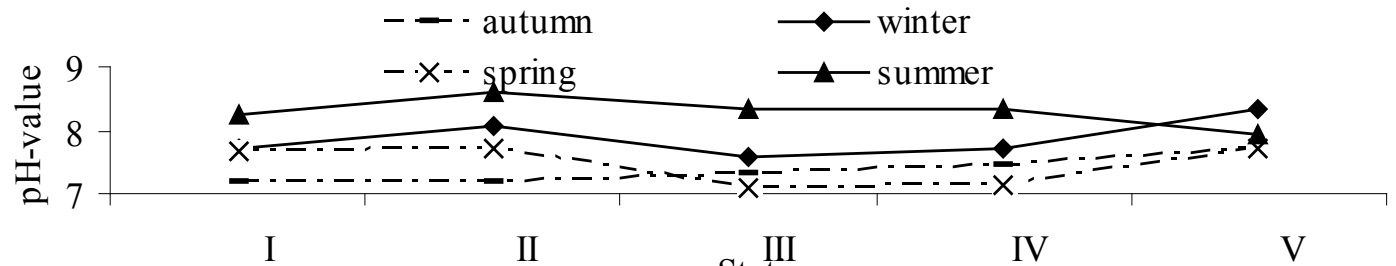

Stations

Figure 8: Seasonal variations of pH-value at studied sites (2014-2015).

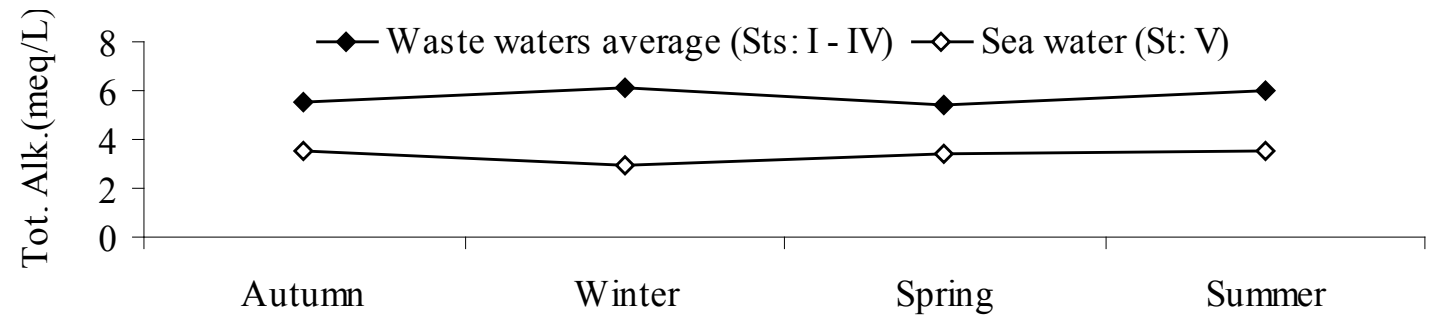

Figure 9: Seasonal total alkalinity averages of waste water sites and seawater (2014-2015). 
Citation: Saad AS, Massoud MA, Amer RA, Ghorab MA (2017) Assessment of the Physico-chemical Characteristics and Water Quality Analysis of Mariout Lake, Southern of Alexandria, Egypt. J Environ Anal Toxicol 7: 421. doi: 10.4172/2161-0525.1000421

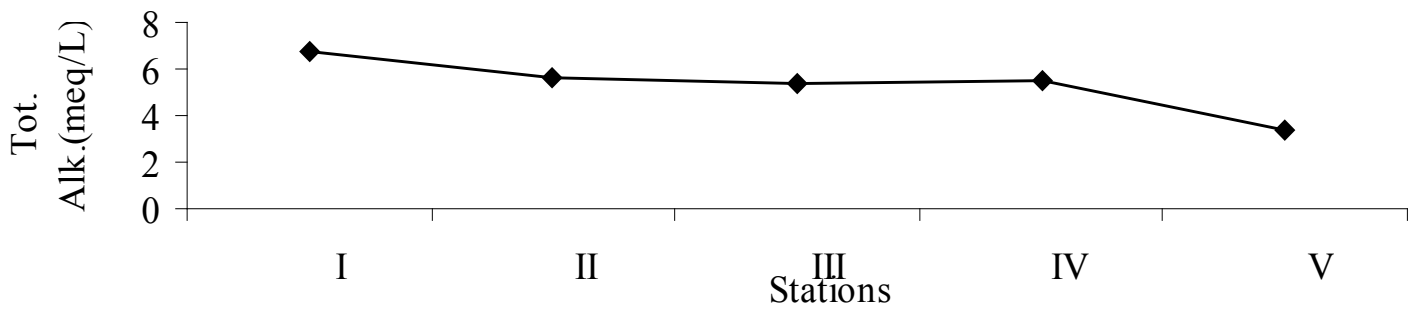

Figure 10: Annual total alkalinity averages at studied sites (2014-2015)

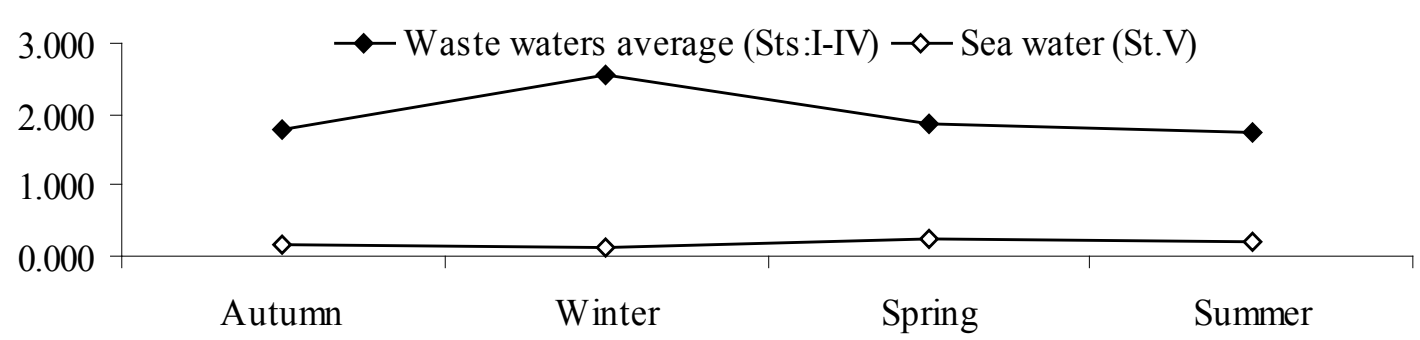

Figure 11: Specific alkalinity values at studied sites (2014-2015).

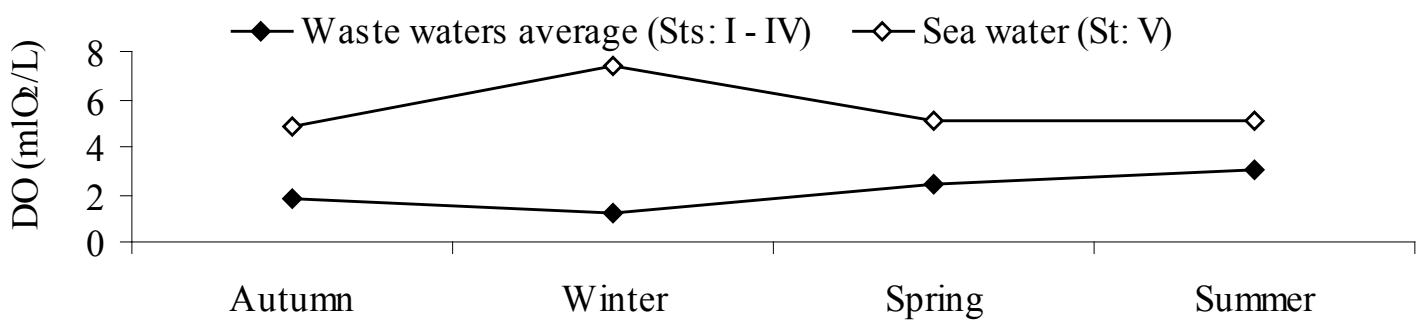

Figure 12: Seasonal dissolved oxygen averages of waste water sites and seawater (2014-2015).

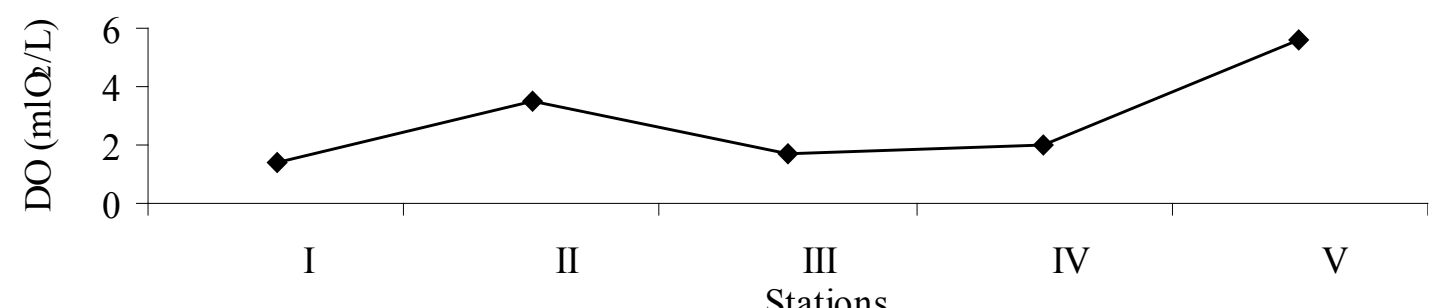

Figure 13: Annual dissolved oxygen averages at studied sites (2014-2015)

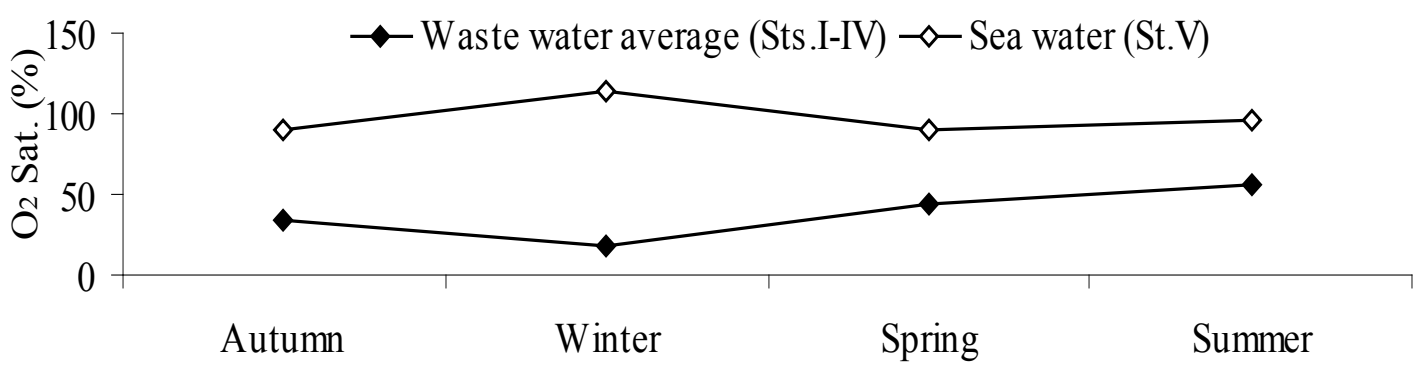

Figure 14: Oxygen saturation (\%) at studied sites (2014-2015). 
Citation: Saad AS, Massoud MA, Amer RA, Ghorab MA (2017) Assessment of the Physico-chemical Characteristics and Water Quality Analysis of Mariout Lake, Southern of Alexandria, Egypt. J Environ Anal Toxicol 7: 421. doi: 10.4172/2161-0525.1000421

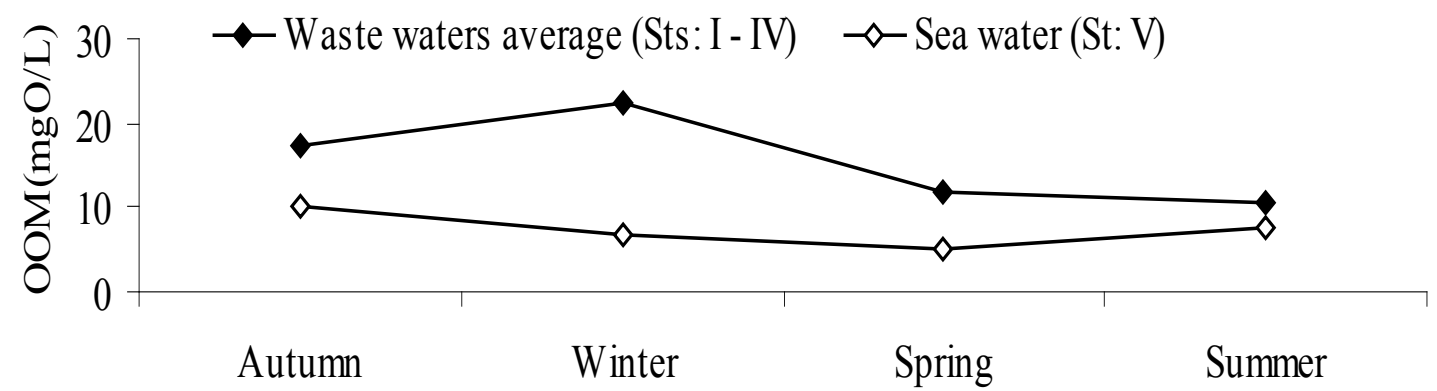

Figure 15: Seasonal oxidizable organic matter averages of waste water sites and seawater (2014-2015).

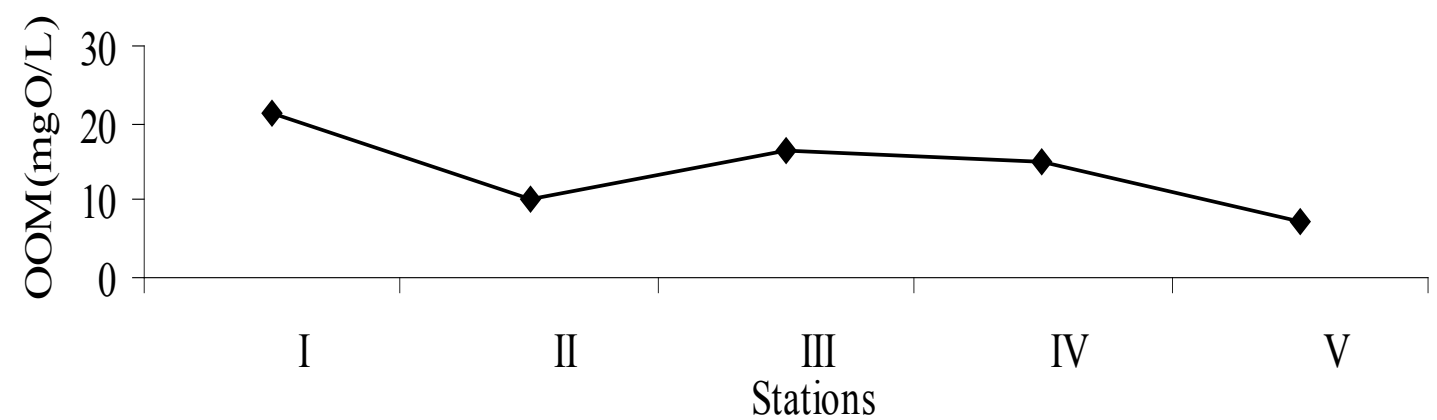

Figure 16: Annual averages of oxidizable organic matter at studied sites (2014-2015).

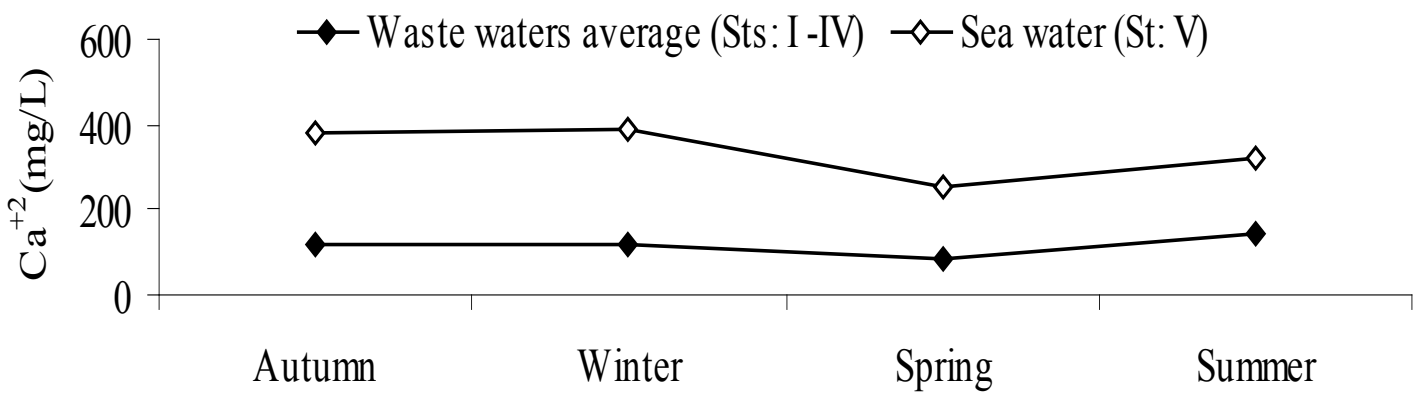

Figure 17: Seasonal calcium averages of waste water sites and seawater (2014-2015).

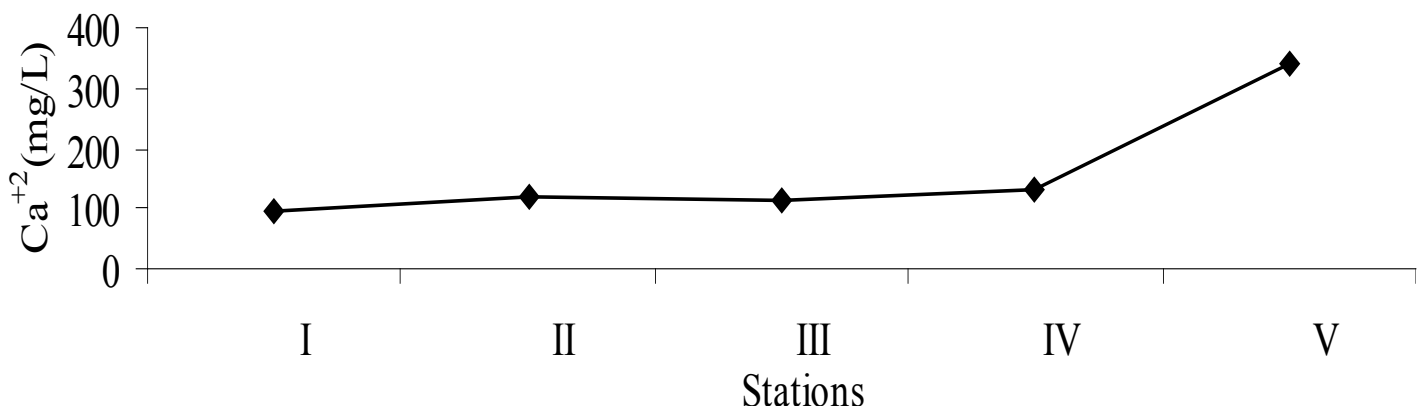

Figure 18: Annual calcium averages at studied sites (2014-2015). 
Citation: Saad AS, Massoud MA, Amer RA, Ghorab MA (2017) Assessment of the Physico-chemical Characteristics and Water Quality Analysis of Mariout Lake, Southern of Alexandria, Egypt. J Environ Anal Toxicol 7: 421. doi: 10.4172/2161-0525.1000421

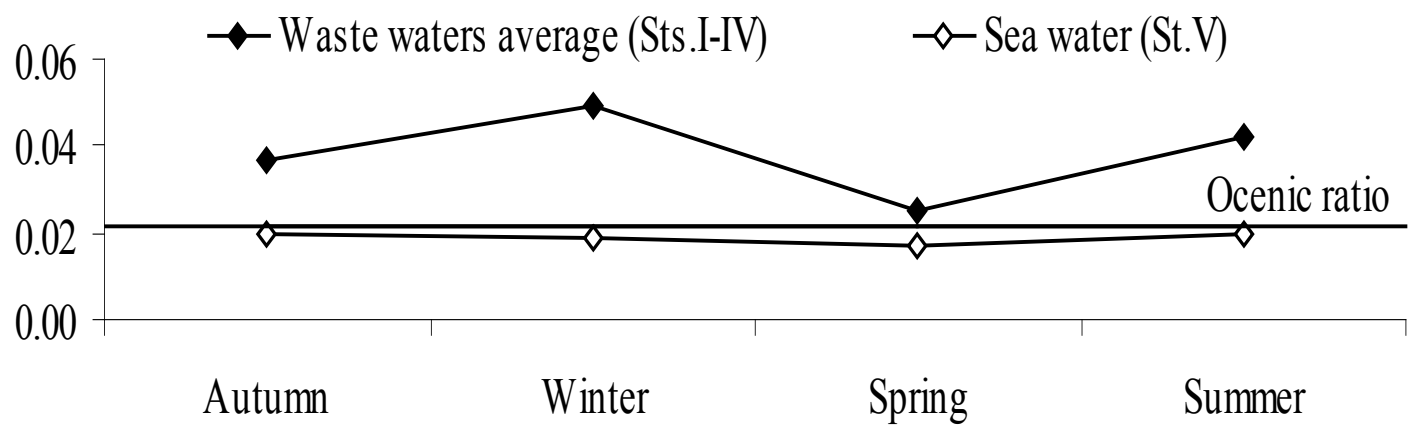

Figure 19: Calcium/chlorinity ratio at studied sites (2014-2015).

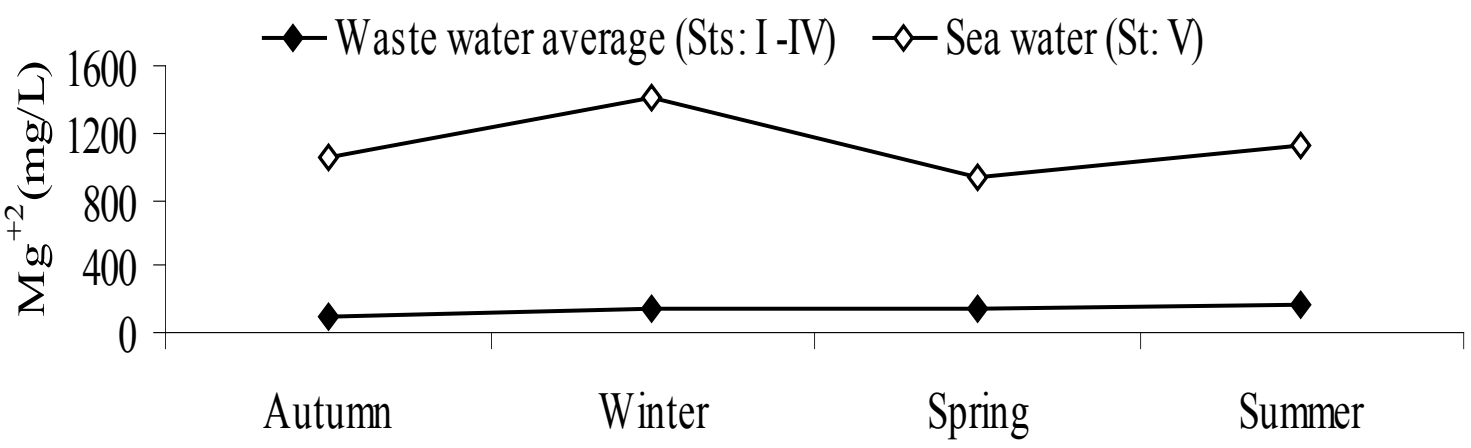

Figure 20: Seasonal magnesium averages of waste water sites and seawater (2014-2015).

ratio, most of waste water stations are lower in their magnesium/ chlorinity ratio $(0.0423$, on average) than the normal oceanic ratio of 0.0669 except for Pump station (III) during winter which attributed to the significant decrease in salinity value of $2.860 \%$, (Figure 22 ). Magnesium/chlorinity ratio at El-Mex Bay station varied between 0.0533 during autumn and 0.0694 during summer with an annual average of 0.0631 which fluctuated more or less than normal oceanic ratio [40-42].

Sodium: The seasonal and regional variations of sodium are presented in Figures 23 and 24. At waste water stations, sodium seasonal averages showed a maximum of $1.9426 \mathrm{gm} / \mathrm{L}$ during winter and a minimum of $1.3896 \mathrm{gm} / \mathrm{L}$ during summer, with an annual average of $1.6710 \mathrm{gm} / \mathrm{L}$. Regionally, El-Umum Drain outlet (IV) showed the highest annual average $(5.4444 \mathrm{gm} / \mathrm{L})$ of waste water sites. El Kalaa Drain (I) recorded the lowest sodium content $(0.1839 \mathrm{gm} / \mathrm{L})$ during winter-spring period. With respect to seawater station $(\mathrm{V})$, the maximum value of $11.8167 \mathrm{gm} / \mathrm{L}$ was observed during winter and minimum of $11.0580 \mathrm{gm} / \mathrm{L}$ during spring, with an annual average of $11.4350 \mathrm{gm} / \mathrm{L}$. The average sodium/chlorinity ratio for waste water sites fluctuated between 0.350-0.618 during summer and winter, with an annual average of 0.433 . At El-Mex Bay station, the highest sodium/ chlorinity ratio of 0.740 was observed during spring and the lowest of 0.576 during winter which are above the normal oceanic ratio $(0.556)$ (Figure 25) [43,44].

Sulphate: Seasonal as well as annual values of sulphate are displayed in Figures 26 and 27. Significant seasonal variations of sulphate content occurred at waste water (Sts.I-IV) which ranged from $262.3 \mathrm{mg} / \mathrm{L}$ during spring to $837.8 \mathrm{mg} / \mathrm{L}$ during summer, with an annual average of $586.5 \mathrm{mg} / \mathrm{L}$ [45]. At El-Mex Bay area, seasonal changes in sulphate content were found to resemble those of calcium, magnesium, and sodium where a winter maximum level of $2856.0 \mathrm{mg} / \mathrm{L}$ followed by a marked drop in spring $(1678.0 \mathrm{mg} / \mathrm{L})$, following the seasonal salinity changes, with an annual average of $2347.5 \mathrm{mg} / \mathrm{L}$. Sulphate/chlorinity ratio of waste water, most the period of study, revealed significant variation which is declined strongly above the oceanic ratio of 0.140 . The surface water of El Kalaa Drain showed marked decrease in sulphate content and chlorinity ratio during winter $(168.0 \mathrm{mg} / \mathrm{L}-0.071)$ and spring $(69.0 \mathrm{mg} / \mathrm{L}-0.030)$. Seawater (St.V), on the other hand, revealed a negative declination in the chlorinity ratio during autumn, winter and spring seasons being $0.126,0.139$ and 0.112 , respectively while summer chlorinity ratio is higher than that of oceanic ratio being 0.145 (Figure 28) [46,47]. Despite that high sulphate/chlorinity ratios at waste water stations were observed during most seasons which account for high sulphate content relative to salinity, sulphate content at seawater station $(\mathrm{V})$ was appeared to be four times greater than those of waste water stations.

\section{Nutrient salts}

Nutrient salts at different sites during the year of the study are reported in Table 4.

Dissolved inorganic nitrogen (DIN): The seasonal DIN averages at waste water sites (I-IV) ranged from $121.0 \mu \mathrm{M}$ to $266.9 \mu \mathrm{M}$ during summer and winter, respectively, with an annual average of $194.8 \mu \mathrm{M}$. At seawater station $(\mathrm{V})$, a maximum DIN concentration $(78.9 \mu \mathrm{M})$ was 
Citation: Saad AS, Massoud MA, Amer RA, Ghorab MA (2017) Assessment of the Physico-chemical Characteristics and Water Quality Analysis of Mariout Lake, Southern of Alexandria, Egypt. J Environ Anal Toxicol 7: 421. doi: 10.4172/2161-0525.1000421

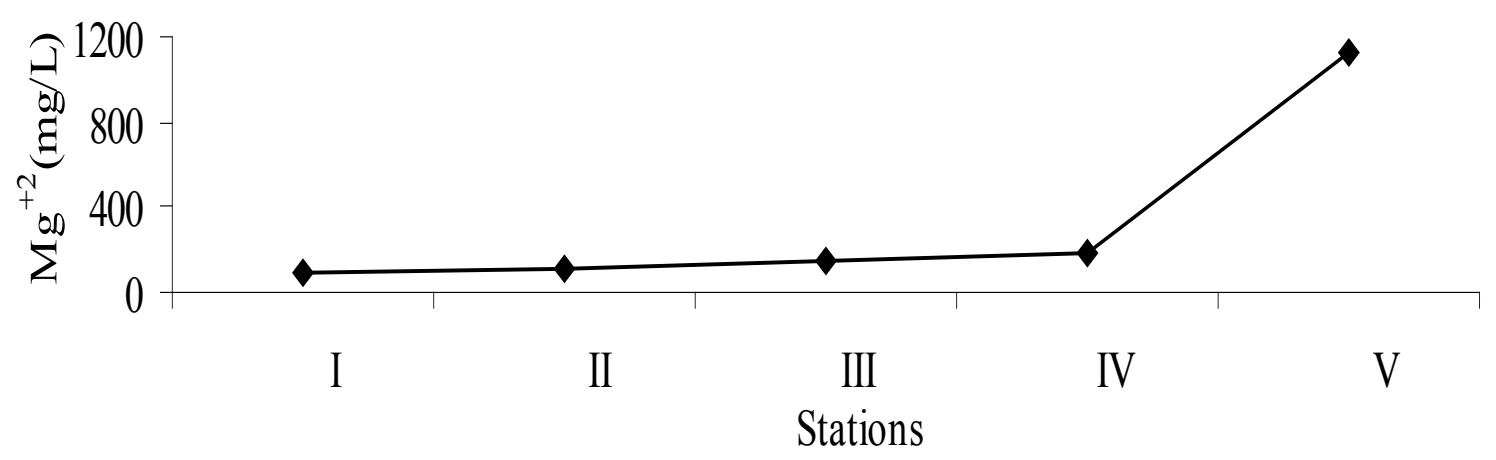

Figure 21: Annual magnesium averages at studied sites (2014-2015).

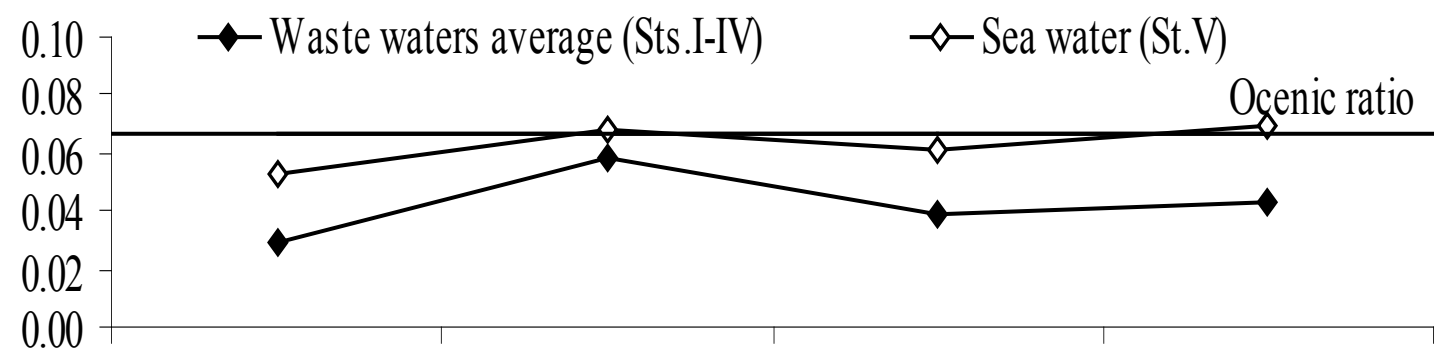

Autumn Winter Spring Summer

Figure 22: Magnesium/chlorinity ratio at studied sites (2014-2015).

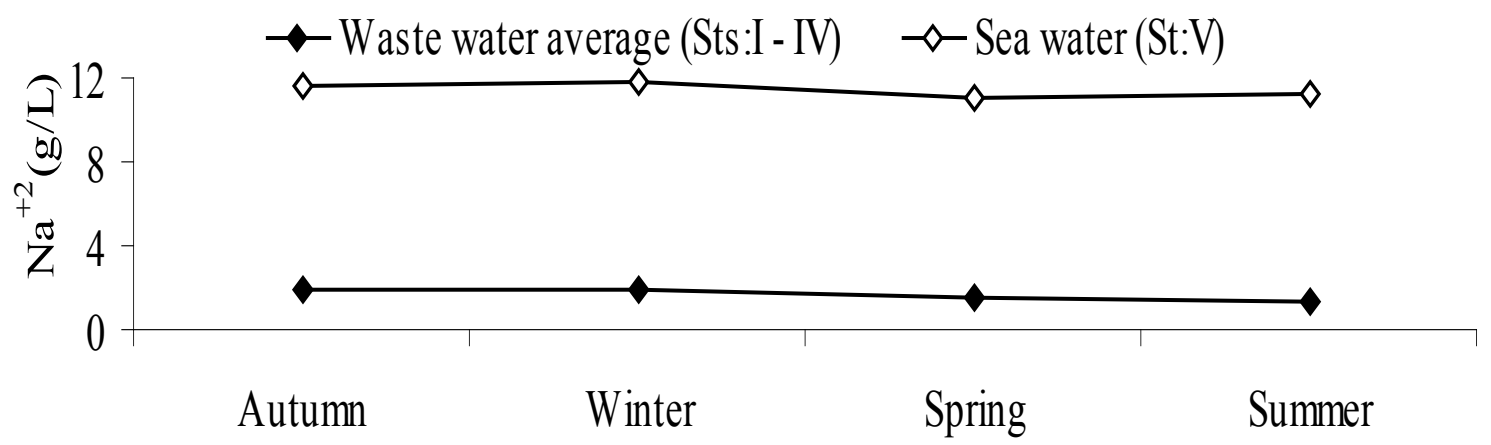

Figure 23: Seasonal sodium averages of waste water sites and seawater (2014-2015).

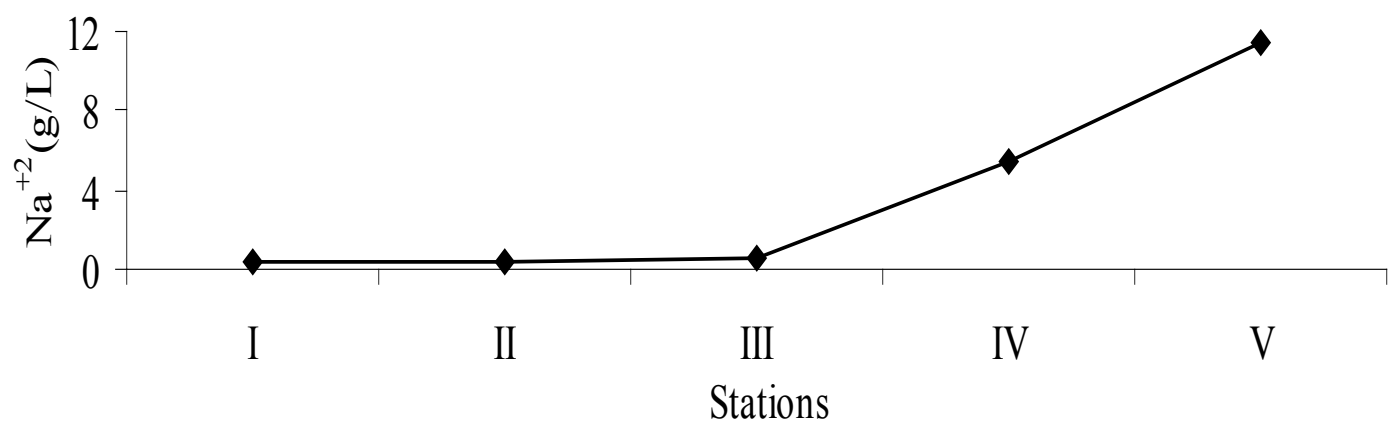

Figure 24: Annual sodium averages at studied sites (2014-2015). 
Citation: Saad AS, Massoud MA, Amer RA, Ghorab MA (2017) Assessment of the Physico-chemical Characteristics and Water Quality Analysis of Mariout Lake, Southern of Alexandria, Egypt. J Environ Anal Toxicol 7: 421. doi: 10.4172/2161-0525.1000421

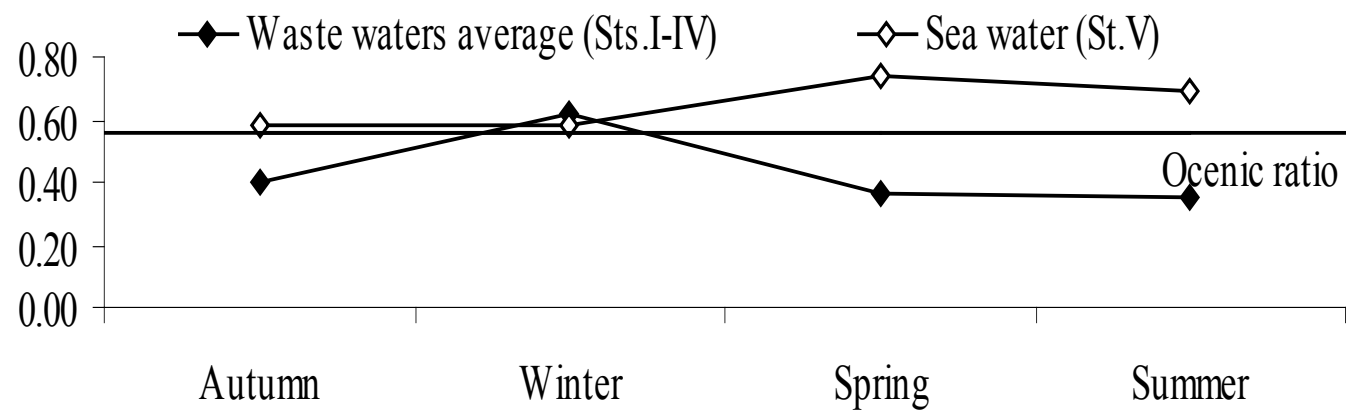

Figure 25: Sodium/chlorinity ratio at studied sites (2014-2015)

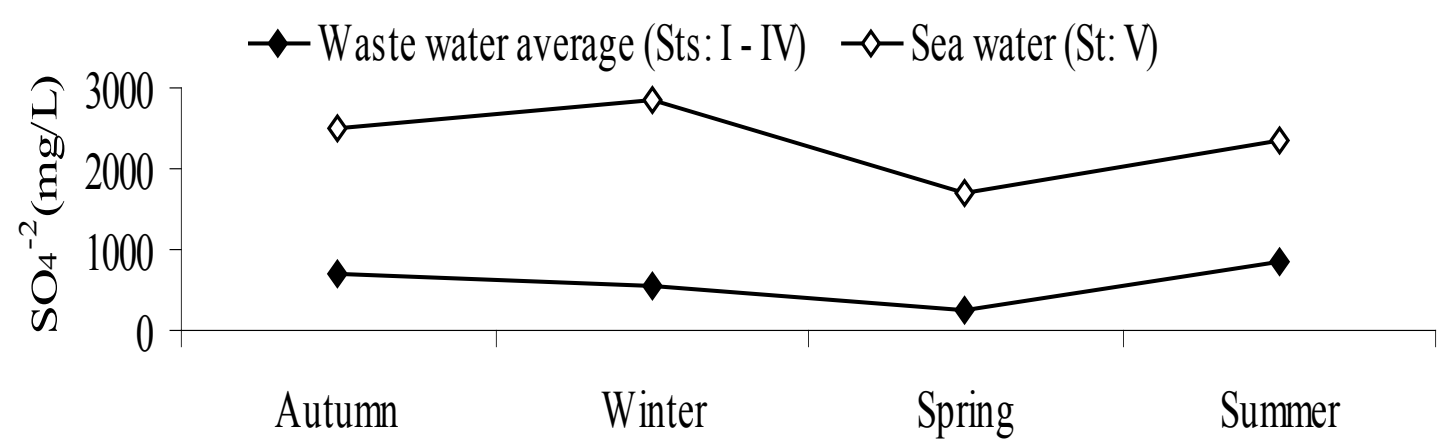

Figure 26: Seasonal sulphate averages of waste water sites and seawater (2014-2015).

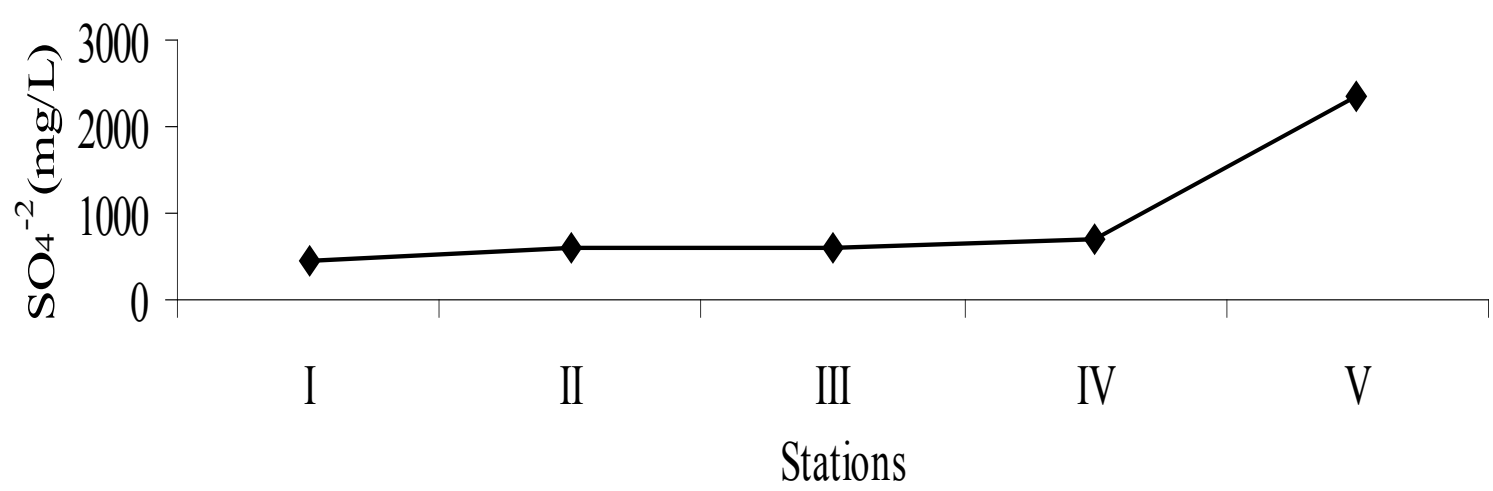

Figure 27: Annual sulphate averages at studied sites (2014-2015).

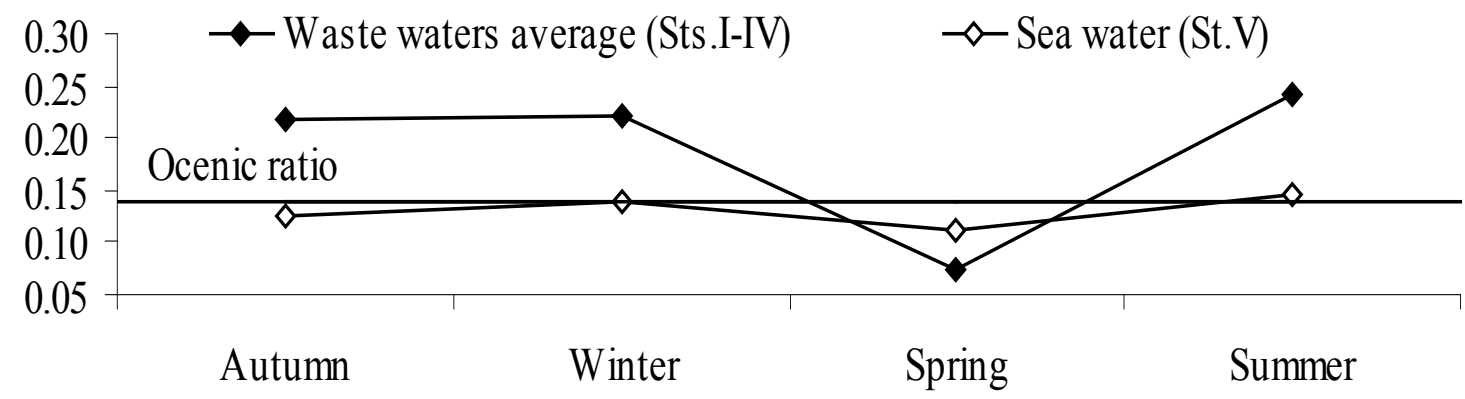

Figure 28: Sulphate/chlorinity ratio at studied sites (2014-2015). 
Citation: Saad AS, Massoud MA, Amer RA, Ghorab MA (2017) Assessment of the Physico-chemical Characteristics and Water Quality Analysis of Mariout Lake, Southern of Alexandria, Egypt. J Environ Anal Toxicol 7: 421. doi: 10.4172/2161-0525.1000421

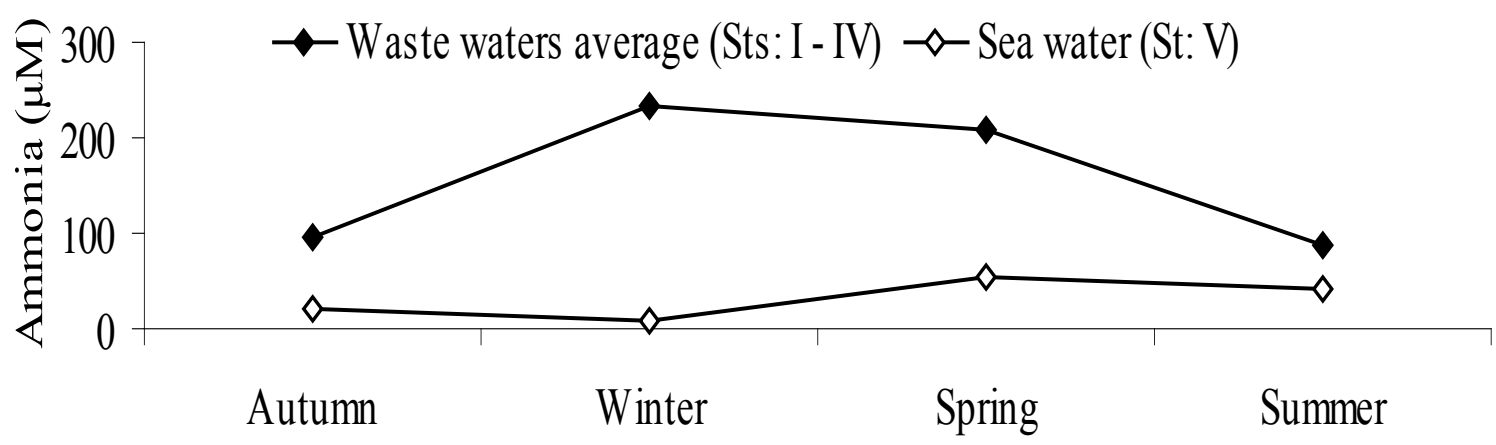

Figure 29: Seasonal ammonia averages of waste water sites and seawater (2014-2015).

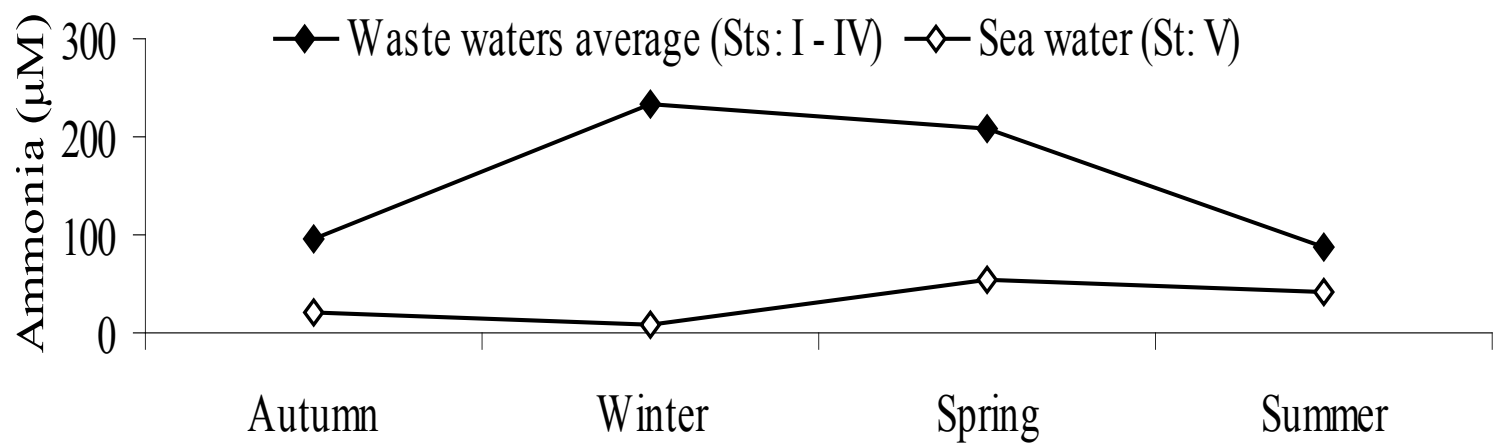

Figure 30: Annual ammonia averages at studied sites (2014-2015).

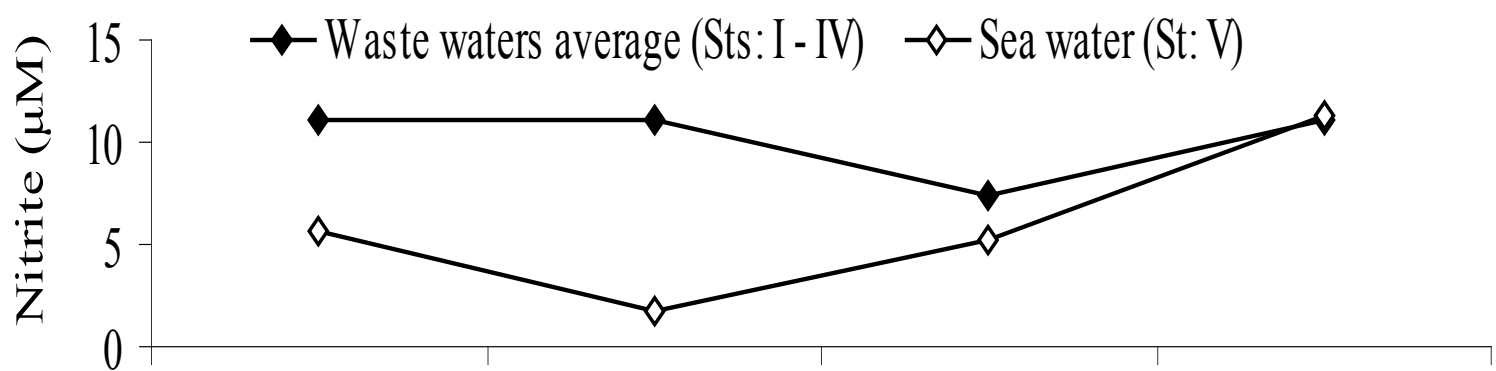

Autumn Winter Spring Summer

Figure 31: Seasonal nitrite averages of waste water stations and seawater (2014-2015).

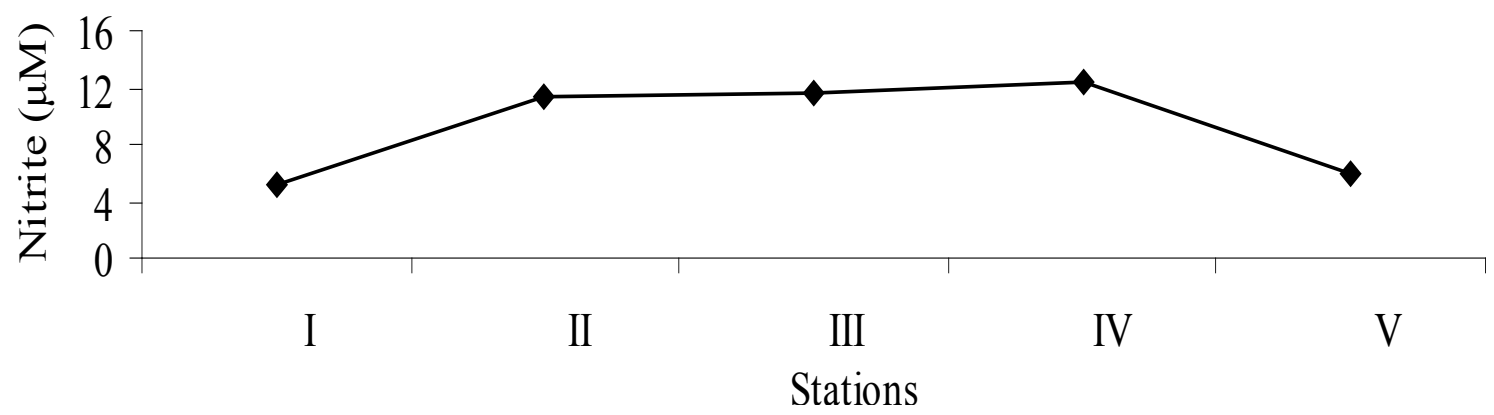

Figure 32: Annual nitrite averages at studied sites (2014-2015) 
Citation: Saad AS, Massoud MA, Amer RA, Ghorab MA (2017) Assessment of the Physico-chemical Characteristics and Water Quality Analysis of Mariout Lake, Southern of Alexandria, Egypt. J Environ Anal Toxicol 7: 421. doi: 10.4172/2161-0525.1000421

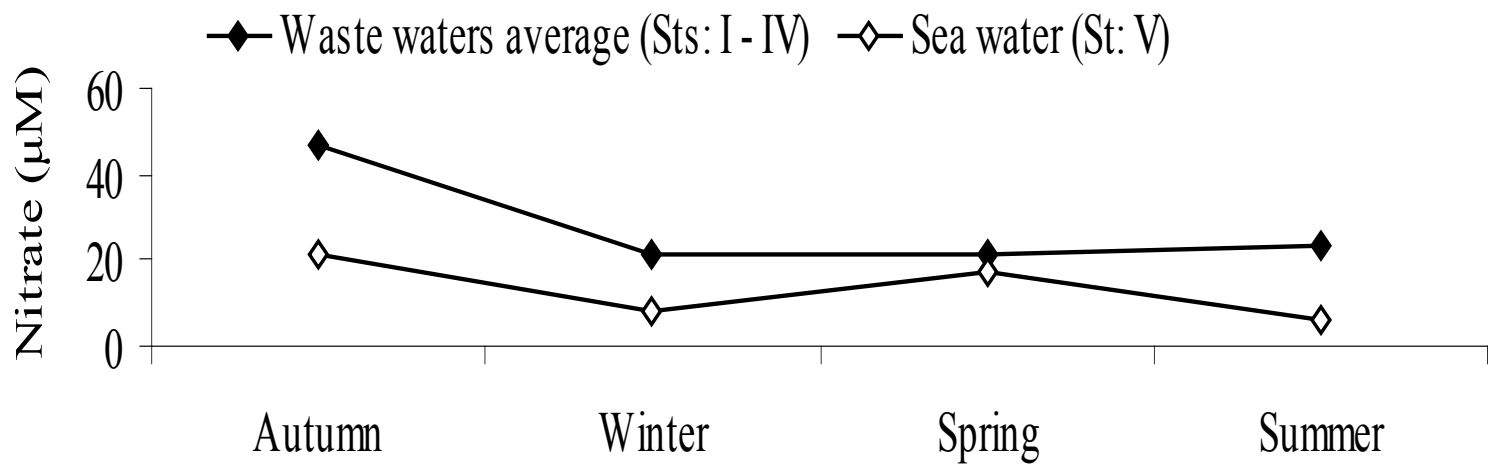

Figure 33: Seasonal nitrate averages of waste water sites and seawater (2014-2015).

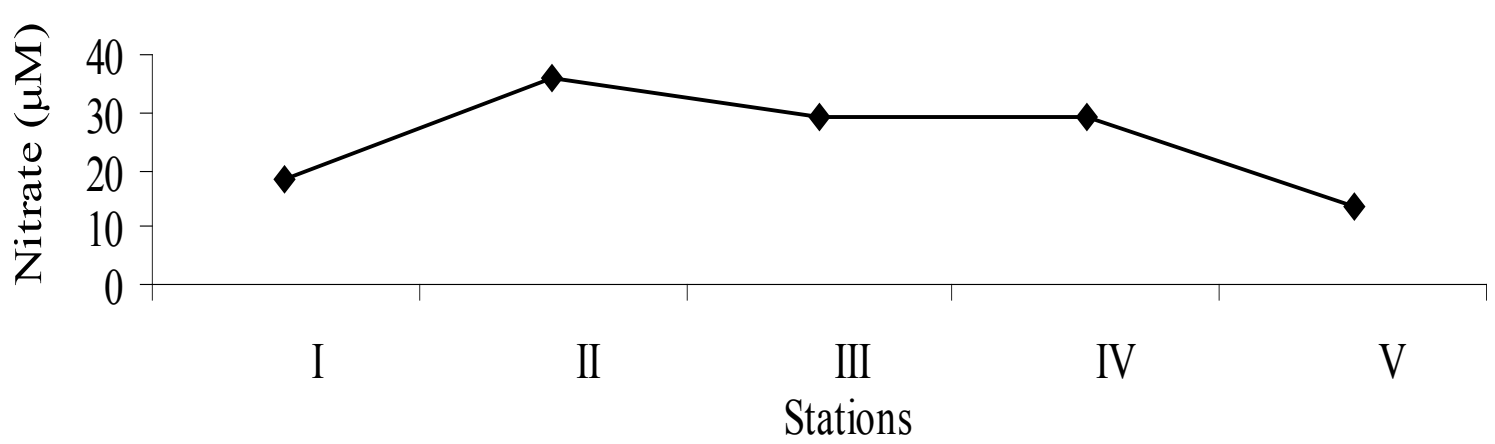

Figure 34: Annual nitrate averages at studied sites during (2014-2015).

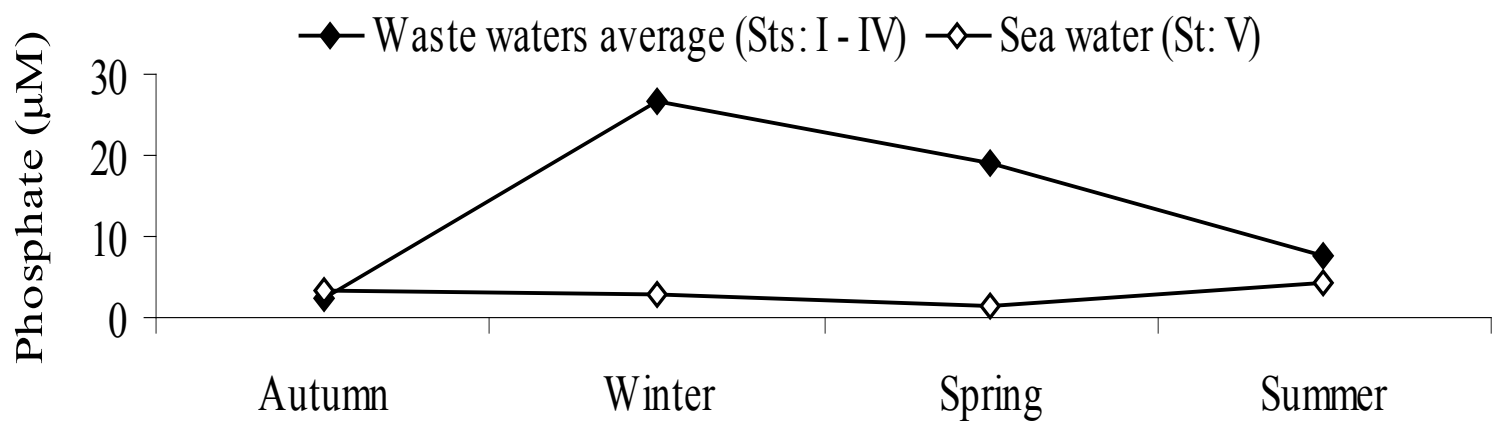

Figure 35: Seasonal phosphate averages of waste water sites and seawater (2014-2015).

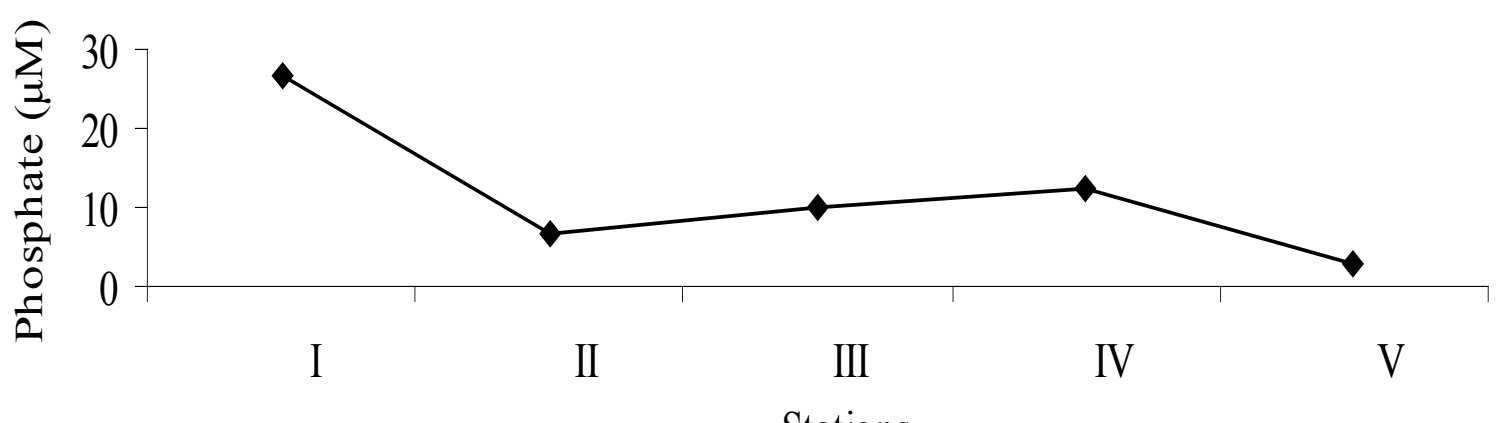

Stations

Figure 36: Annual phosphate averages at studied sites (2014-2015). 
Citation: Saad AS, Massoud MA, Amer RA, Ghorab MA (2017) Assessment of the Physico-chemical Characteristics and Water Quality Analysis of Mariout Lake, Southern of Alexandria, Egypt. J Environ Anal Toxicol 7: 421. doi: 10.4172/2161-0525.1000421

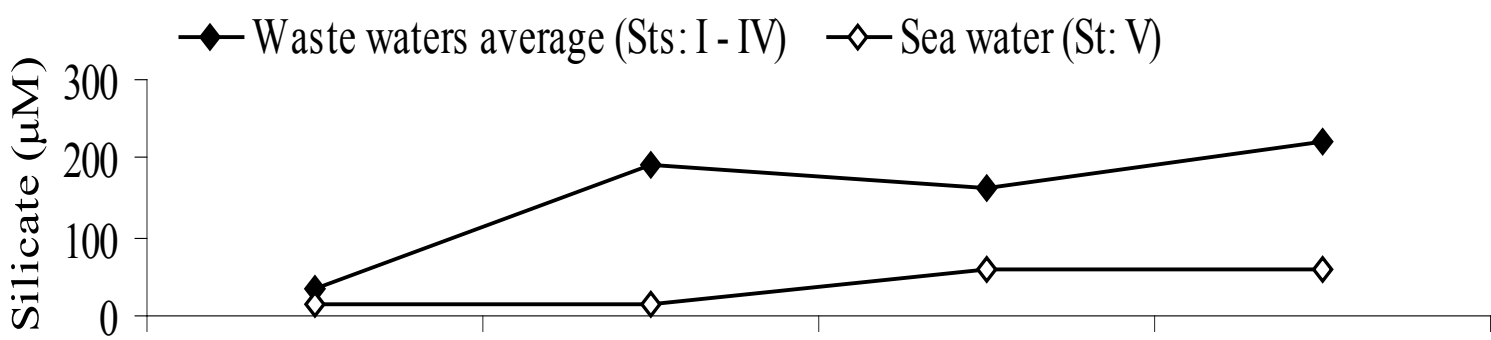

Autumn Winter Spring Summer

Figure 37: Seasonal silicate averages of waste water stations and seawater (2014-2015).

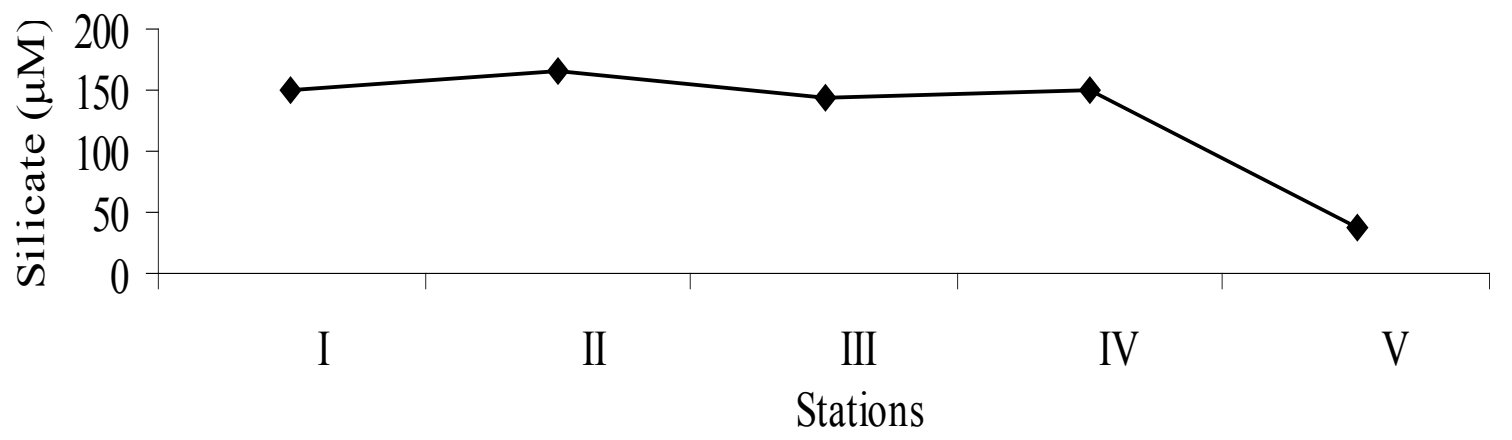

Figure 38: Annual silicate averages at studied sites (2014-2015).

\begin{tabular}{|c|c|c|c|c|c|c|c|c|}
\hline \multirow{2}{*}{ Seasons } & \multirow{2}{*}{ Stations } & $\mathrm{NH}_{3} / \mathrm{N}$ & $\mathrm{NO}_{2} / \mathrm{N}$ & $\mathrm{NO}_{3} / \mathrm{N}$ & $\mathrm{PO}_{4} / \mathrm{P}$ & $\mathrm{SiO}_{3} / \mathrm{Si}$ & DIN & N/P \\
\hline & & $(\mu \mathrm{M})$ & $(\mu \mathrm{M})$ & $(\mu \mathrm{M})$ & $(\mu \mathrm{M})$ & $(\mu \mathrm{M})$ & $(\mu \mathrm{M})$ & \\
\hline \multirow{6}{*}{ 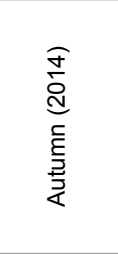 } & 1 & 12.8 & 14.5 & 51.2 & 1.8 & 32.9 & 78.5 & 43.6 \\
\hline & II & 19.4 & 10.8 & 47.2 & 2.9 & 37.2 & 77.4 & 26.7 \\
\hline & III & 254.0 & 9.8 & 42.6 & 1.2 & 19.5 & 306.4 & 255.3 \\
\hline & IV & 96.3 & 8.8 & 47.1 & 4.3 & 45.1 & 152.2 & 35.4 \\
\hline & $\begin{array}{c}\text { Seasonal average } \\
(\text { I-IV) }\end{array}$ & 95.6 & 11.0 & 47.0 & 2.6 & 33.7 & 153.6 & 90.3 \\
\hline & $\mathrm{V}$ & 18.9 & 5.6 & 21.2 & 3.4 & 14.5 & 45.7 & 13.4 \\
\hline \multirow{6}{*}{ 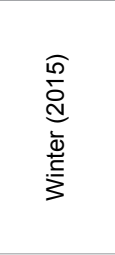 } & 1 & 155.0 & 0.3 & 0.7 & 54.1 & 179.3 & 156.0 & 2.9 \\
\hline & II & 61.4 & 15.9 & 32.7 & 10.7 & 214.1 & 110.0 & 10.3 \\
\hline & III & 373.8 & 12.4 & 27.5 & 18.9 & 182.5 & 413.7 & 21.9 \\
\hline & IV & 348.6 & 15.5 & 23.8 & 22.6 & 182.5 & 387.9 & 17.2 \\
\hline & $\begin{array}{c}\text { Seasonal average } \\
(\mathrm{I}-\mathrm{IV})\end{array}$ & 234.7 & 11.0 & 21.2 & 26.6 & 189.6 & 266.9 & 13.1 \\
\hline & $\mathrm{V}$ & 9.6 & 1.8 & 8.3 & 2.7 & 14.6 & 19.7 & 7.3 \\
\hline \multirow{6}{*}{$\begin{array}{l}\widehat{10} \\
\text { 엉 } \\
\text { D } \\
\text { के } \\
\text { के }\end{array}$} & $\mathrm{I}$ & 563.0 & 0.0 & 1.7 & 44.1 & 162.3 & 564.7 & 12.8 \\
\hline & II & 39.0 & 10.5 & 31.6 & 7.5 & 179.9 & 81.1 & 10.8 \\
\hline & III & 123.5 & 8.4 & 28.5 & 11.7 & 163.0 & 160.4 & 13.7 \\
\hline & IV & 110.0 & 10.7 & 24.3 & 13.7 & 152.1 & 145.0 & 10.6 \\
\hline & $\begin{array}{c}\text { Seasonal average } \\
(\mathrm{I}-\mathrm{IV})\end{array}$ & 208.9 & 7.4 & 21.5 & 19.2 & 164.3 & 237.8 & 12.0 \\
\hline & $\mathrm{V}$ & 56.2 & 5.2 & 17.4 & 1.5 & 59.6 & 78.9 & 52.6 \\
\hline \multirow{6}{*}{ 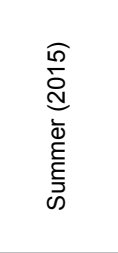 } & 1 & 25.0 & 5.6 & 20.8 & 5.7 & 228.2 & 51.4 & 9.0 \\
\hline & II & 39.0 & 8.0 & 31.8 & 6.4 & 226.3 & 78.8 & 12.3 \\
\hline & III & 141.2 & 15.8 & 18.7 & 7.7 & 216.0 & 175.7 & 22.8 \\
\hline & IV & 142.7 & 15.1 & 20.3 & 9.9 & 217.1 & 178.1 & 18.0 \\
\hline & $\begin{array}{l}\text { Seasonal average } \\
(\text { I-IV) }\end{array}$ & 87.0 & 11.1 & 22.9 & 7.4 & 221.9 & 121.0 & 15.5 \\
\hline & $\mathrm{V}$ & 42.0 & 11.3 & 6.3 & 4.1 & 56.6 & 59.6 & 14.5 \\
\hline
\end{tabular}


Citation: Saad AS, Massoud MA, Amer RA, Ghorab MA (2017) Assessment of the Physico-chemical Characteristics and Water Quality Analysis of Mariout Lake, Southern of Alexandria, Egypt. J Environ Anal Toxicol 7: 421. doi: 10.4172/2161-0525.1000421

Page 17 of 19

\begin{tabular}{|c|c|c|c|c|c|c|c|c|}
\hline \multirow{6}{*}{ 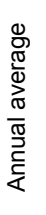 } & I & 188.9 & 5.1 & 18.6 & 26.4 & 150.7 & 212.6 & 17.1 \\
\hline & II & 39.7 & 11.3 & 35.8 & 6.9 & 164.4 & 86.8 & 15.0 \\
\hline & III & 223.1 & 11.6 & 29.3 & 9.9 & 145.2 & 264.0 & 78.4 \\
\hline & IV & 174.4 & 12.5 & 28.9 & 12.6 & 149.2 & 215.8 & 20.3 \\
\hline & I-IV & 156.5 & 10.1 & 28.2 & 14.0 & 152.4 & 194.8 & 32.7 \\
\hline & V & 31.7 & 6.0 & 13.3 & 2.9 & 36.3 & 51.0 & 22.0 \\
\hline
\end{tabular}

Table 4: Nutrient salts $(\mu \mathrm{M})$ at El-Mex area during (2014-2015).

observed during spring while a minimum value $(19.7 \mu \mathrm{M})$ was recorded during winter, with an annual average of $51.0 \mu \mathrm{M}$ (Table 4) $[48,49]$.

Ammonia: Figures 29 and 30 represent the changes in the concentration of ammonia during the period of study. Ammonia concentration at waste water stations attended a maximum value during winter and a minimum value during summer being 234.7 $\mu \mathrm{M}$ and $87.0 \mu \mathrm{M}$, respectively, with an annual average of $156.5 \mu \mathrm{M}$. Regionally, abrupt increase in ammonia content is observed at El Kalaa Drain during spring being $563.0 \mu \mathrm{M}$. El-Umum site (St.II) had much lower ammonia content (Figure 30). Its maximum value was $61.4 \mu \mathrm{M}$ during winter while minimum value of $19.4 \mu \mathrm{M}$ was recorded during autumn. With respect to El-Mex Bay station (St.V), spring represented the highest value $(56.2 \mu \mathrm{M})$ and winter the lowest value $(9.6 \mu \mathrm{M})$, with an annual average of $31.7 \mu \mathrm{M}$. Although the amount of ammonia in the seawater (St.V) is small (one-fifth, on average) compared with that of waste waters, ammonia concentration at El-Mex Bay station $(\mathrm{V})$ is still relatively high if compared with normal seawater. El-Mex water enriched with ammonia during spring-summer period being $56.2 \mu \mathrm{M}$ and $42.0 \mu \mathrm{M}$, respectively [50,51].

Nitrite: The seasonal variations as well as annual averages of nitrite are illustrated in Figures 31 and 32. Slight seasonal variations in nitrite concentration at waste water stations appeared to range from $7.4 \mu \mathrm{M}$ during spring to $11.1 \mu \mathrm{M}$ during summer, with an annual average of 10.1 $\mu \mathrm{M}$. Regionally, absence of nitrite is accompanied by an increase in ammonia at El Kalaa Drain during spring. With respect to El-Mex Bay station, nitrite concentration showed a maximum concentration of $11.3 \mu \mathrm{M}$ and a minimum of $1.8 \mu \mathrm{M}$ during summer and winter, respectively, with an annual average of $6.0 \mu \mathrm{M}$.

Nitrate: Figures 33 and 34 display the changes of nitrate concentration through the year of study. With respect to seasonal averages at waste waters (Sts.I-IV), winter, spring and summer reported nearly identical levels around $22 \mu \mathrm{M}$. Autumn, on the other hand, exhibited relative high average, two times greater than any other seasons (Figure 3). Slight seasonal fluctuations were found at ElUmum station $(\mathrm{V})$ which attained a maximum value during autumn and a minimum value during summer being $21.2 \mu \mathrm{M}$ and $6.3 \mu \mathrm{M}$, respectively, with an annual average of $13.3 \mu \mathrm{M}$.

Dissolved inorganic phosphate: Figures 35 and 36 show the variations in phosphate concentration at El-Mex area during (20142015). Phosphate concentration in brackish water was $2.6 \mu \mathrm{M}$ in autumn period, increased to $26.6 \mu \mathrm{M}$ in the succeeding winter followed by a decrease from spring till summer, with an annual average of 14.0 $\mu \mathrm{M}$ (Figure 5). Regionally, El Kalaa Drain showed high values during winter and spring being $54.1 \mu \mathrm{M}$ and $44.1 \mu \mathrm{M}$, respectively. Seawater, on the other hand, showed a narrow range $(1.5 \mu \mathrm{M}-4.1 \mu \mathrm{M})$, with an annual average of $2.9 \mu \mathrm{M}$ [51].

\section{$\mathrm{N} / \mathrm{P}$ ratio}

The annual average N/P ratios for the present work are 32.7 and 22.0 for waste and saline waters, respectively. At waste water stations (I-IV),
$\mathrm{N} / \mathrm{P}$ ratio decreased from 90.3 during autumn to 13.1 during winter reaching a minimum value during spring (12.0). Summer showed N/P ratio being 15.5 which was close to the normal one. However, little variations were recorded at seawater location (St.V) where N/P ratio reached a maximum level of 52.6 during spring and minimum levels of 13.4, 7.3 and 14.5 during autumn, winter and summer, respectively, which are lower than normal one.

\section{Silicate}

The seasonal changes in silicate concentration are illustrated in Figures 37 and 38. Significant changes in silicate content were demonstrated at waste water sites, ranging from $33.7 \mu \mathrm{M}$ during autumn to about $221.9 \mu \mathrm{M}$ during summer, with an annual average of $152.4 \mu \mathrm{M}$. The waste water at the area of study exhibits silicate content four times greater or more than that at seawater (on, average). It is noticeable that the silicate concentrations at ELummum station varied from maximum values of $59.6 \mu \mathrm{M}$ and $56.6 \mu \mathrm{M}$ during spring and summer and minima of $14.5 \mu \mathrm{M}$ and $14.6 \mu \mathrm{M}$ during autumn and winter, respectively (Figure 37).

\section{Conclusions}

Mariout Lake has received domestic, industrial, and agricultural wastewater from the its surrounding area. In order to study the effect of anthropogenic influence and environmental toxicology study on ecosystem several water samples have been analyzed for physicochemical characteristics and water quality analyses. The present data show more significant variations in the eutrophication parameter levels. The present study throws light on the following:

1. The difference between the data of the previous studies and that of the present one reflects an increase in the pollution status of Mariout Lake during the last three decades.

2. There was a noticeable variation in ammonia levels. This is probably due to the utilization of $\mathrm{NH}_{4}-\mathrm{N}$ by phytoplankton, in addition to the reduction of $\mathrm{NO}_{3}$ to $\mathrm{NH}_{4}-\mathrm{N}$ via a denitrification process.

3. Nitrate and ammonia fluctuations may be due to microbial utilization as well as to the varying agricultural inflows.

4. The higher concentrations of reactive phosphate are mostly due to the effect of drainage water enriched with phosphorous compounds.

5. The low values of N/P ratio may be a result of an allochthonous condition from the drainage of wastewater. This could suggest that nitrogen is the most limiting factor for the growth of phytoplankton.

\section{Acknowledgements}

The authors wish to express their gratitude to Dr. Ahmed Abdelhalim, Marine Chemistry Lab, and all staff at the Central Laboratories Unit, National Institute of Oceanography and Fisheries (NIOF) for help and Support to obtaining the samples required for the present study. Our special thanks are offered to Prof. Mamdouh Fahmy, the PI of the project. Thanks, are appreciated also to Dr. Hamza Samir, for his valuable help during this Study. 
Citation: Saad AS, Massoud MA, Amer RA, Ghorab MA (2017) Assessment of the Physico-chemical Characteristics and Water Quality Analysis of Mariout Lake, Southern of Alexandria, Egypt. J Environ Anal Toxicol 7: 421. doi: 10.4172/2161-0525.1000421

Page 18 of 19

\section{References}

1. Singh SP, Deepa P, Rashmi S (2002) Hydrobiological Studies of two ponds of Satna (MP) India. Eco Environ Cons 8: 289-292.

2. Shriadah MA, Emara I (1992) Iron, Manganes, Nickel, Lead and Cadmium in fish and crustacean from the Eastern Harbour and El-Mex Bay of Alexandria. Bulletin High Institutes 22: 515-525

3. Shriadah MA, Emara I (1992b) Major cations and alkalinity in the Eastern harbor and El-MexBey. Bull Fac Sci Alex Univ 32: 156-174.

4. Said MA, El-Deek MS, Mahmoud TH, Shriadah MA (1994) Effect of pollution on the hydrochemical characteristics of different water types in El-Mex Bay area, west of Alexandria, Egypt. Acta Adriatica 34: 9-19.

5. Fahmy MA, Tayel FT, Shriadah MA (1997) Spatial and seasonal variations of dissolved trace metals in two contaminated basins of the coastal Mediterranean Sea, Alexandria, Egypt. Bulletin Faculty of Science, Alexandria University 37 : 187-198.

6. Shriadah MA, Said TO, Younis AM, Farag RS (2006) Physico-chemica characteristics of the semi-closed areas along the Mediterranean Coast of Alexandria, Egypt. Egypt J Aquat Res 32: 38-48.

7. Shriadah MA, Said TO, Younis AM, Farag RS (2006) Speciation of Organotin Compounds in Sediments of semi- closed areas along the Mediterranean Coast of Alexandria. Chem Ecol 22: 395-404.

8. Shaltout NA (2008) Inorganic Carbon Cycle of Alexandria Coastal Water. PhD Thesis, Chemistry Department, Faculty of Science, Alexandria University, Egypt, p: 257.

9. Fathy SA, Hamid FFA, Shreadah MA, Mohamed LA, El-Gazar MG (2012) Application of principal component analysis for developing water quality index for selected coastal areas of Alexandria Egypt. Resour Environ 2: 297-305.

10. Stanley JD, Jorstad TF, Gooddio F (2006) Human impact on sediment mass movement and submergence of ancient sites in the two harbours of Alexandria. Egypt Norwegian J Geol 86: 337-350.

11. Mahmoud TH, Masoud MS, Shaltout NA (2005) Physico-chemical characteristics of different water types in El-Mex bay, Alexandria, Egypt. In: Proceedings of OCEANS 2005 MTS/IEEE, pp: 2838-2849.

12. Abdallah MAM (2007) Speciation of trace metals in coastal sediments of ElMex bay south Mediterranean Sea-west of Alexandria (Egypt). Environ Monit Assess 132: 111-123.

13. Abdallah MAM (2008) Trace metal behavior in Mediterranean-climate coasta bay: El-Mex Bay, Egypt and its coastal environment. Glob J Environ Res 2: 23-29.

14. Abdel Ghani SA, Shobier AH, Shreadah MA (2013) Assessment of arsenic and vanadium pollution in surface sediments of the Egyptian Mediterranean coast. Int J Environ Technol Manag 16: 82-101.

15. Carlson RE (1977) A trophic state index for lakes. Limnol Oceanogr 22: 361-369.

16. Carret DE, Carpenter JH (1966) Comparison and evaluation of currently employed modifications of the Winkler Method of determining dissolved oxygen in Sea water. A Nasco Report. J Mar 24: 286-318.

17. Chester R (2000) Marine Geochemistry. 2nd edn. Black Well Science Ltd. USA, p: 493

18. Cloern JE (2001) Our evolving conceptual model of the coastal eutrophication problem. Mar Ecol Prog Ser 210: 223-253.

19. Cole GA (1979) Text Book of Limnology. 2nd edn. CV Mosby Company, USA, p: 426.

20. Davis JC (1986) Statistics and Data Analysis in Geology. John Wiley \& Sons. Inc., New York, USA.

21. Duursma EK (1961) Dissolved organic carbon, nitrogen, and phosphorus in the sea. J Sea Res 1: 1-141.

22. EEAA (2009) A scientific report of Alexanderia integrated coastal zone management project. Environmental and social impact Assessment, p: 113.

23. El-Gindy A, Abouldahab O, Halim Y (1986) Preliminary estimation of water and trace metals balances in EL-Mex Bay, west of Alexandria. Rapp Com Ins Mer Medit 30: 127

24. Emara HI, Shriadah MA, Moustafa TH, El-Deek MS (1992) Effects of sewage and industrial wastes on the chemical characteristics of the Eastern Harbour and El-Mex Bay waters of Alexandria, Egypt. Science of the Total Environment
(Netherlands), pp: 773-784

25. Emara HI, Shriadah MA, Moustafa TH, El-Deek MS (1995) Trace MetalsNutrient Salts Relationship in Coastal Seawater of Alexandria. In: Proc MEDCOAST 95: 1457-1464.

26. Environmental Control and Public Health (ECPH) (1975) Water analysis standard and treatment. Eyro \& Spottiswood Ltd., p: 131

27. El Zokm GM, El-Gohary SE, Abd-El-Khalek DE (2012) Studies of some heavy metals in water and sediment in el-max fish farm, Egypt. World Appl Sci J 18: 171-180.

28. FAO (1975) Permanganate values of organic matter in natural waters. Fisheries Technical Paper 137: 169-171.

29. Faragallah HM, Askar Al, Okbah MA, Moustafa HM (2009) Physico-chemical characteristics of the open Mediterranean Sea water far about $60 \mathrm{Km}$ from Damietta harbor, Egypt. J Ecol Nat Environ 1: 106-119.

30. Hamdy R, Dorgham MM, El-Rashidy HH, Atta MM (2014) Biometry and reproductive biology of Pseudonereis anomala Gravier 1901 (Polychaeta: Nereididae) on the Alexandria coast, Egypt. Oceanologia 56: 41-58.

31. Hutchinson GE (1957) A Treatise on Limnology (Geography, Physics, and Chemistry). John Wiley and Sons. Inc., New York, USA.

32. Lohani BN, Todino G (1984) Water quality index for Chao Phraya river. J Environ Eng 110: 1163-1176.

33. Nessim RB, Bassiouny AR, Zaki HR, Moawad MN, Kandeel KM (2010) Environmental studies at El-Mex region (Alexandria-Egypt) During 2007-2008. World Appl Sci J 9: 779-787.

34. Okbah MA, Ibrahim AMA, Gamal MNM (2013) Environmental monitoring of linear alkylbenzene sulfonates and physicochemical characteristics of seawater in El-Mex Bay (Alexandria, Egypt). Environ Monit Assess 185: 3103-3115.

35. Okbah MA (2005) Nitrogen and phosphorus species of Lake Burullus water (Egypt). Egypt J Aquat Res 31: 186-198.

36. Olobaniyi SB, Owoyemi FB (2006) Characterization by factor analysis of the chemical facies of groundwater in the Deltaic plain sands Aquifer of Warr Western Niger Delta, Nigeria. Afr J Sci Technol 7: 73-81.

37. Riley JP, Chester $\mathrm{CH}$ (1971) Introduction of marine chemistry. Academic Press, London-New York, p: 465.

38. Shams-El-Din NG, Dorgham MM (2007) Phtoplankton community in Abu-Qir Bay as a Hot spot on the southeastern Mediterranean Coast. Egypt Journal of Aquatic research 33: 163-182.

39. Shobier AH, Abdel Ghani SA, Shreadah MA (2011) Distribution of Tota Mercury in Sediments of Four Semi-Enclosed Basins along the Mediterranean Coast of Alexandria. Egypt J Aquat Res 37: 1-11.

40. Shreadah MA, Abdel Moneim MI, Said TO, Fathallah EMI, Mahmoud ME (2013) PAHs in Seawater of the Semi-Closed Areas along the Alexandria Coast of Egyptian Mediterranean Sea. J Environ Prot 4: 1307-1317.

41. Shriadah MA, Emara HI (1996) Heavy metals (Iron, manganese, nickel, Cadmium, and Lead) in the sediments from the Eastern harbor and El-Mex Bay of Alexandria, Egypt. Proc 6th Int Symp Environ Prot, pp: 916- 927.

42. Shreadah MA, Said TO, Abdel Moniem MI, Fathallah EI, Mahmoud ME (2011) PAHs in Sediments along the Semi-closed Areas of Alexandria. Egypt $\mathrm{J}$ of Environ Prot 2: 700-709.

43. Shreadah MA, Said TO, Abdel Moniem MI, Fathallah El, Mahmoud ME (2012) Polychlorinated biphenyls and chlorinated pesticides in Sediments along the Semi-closed Areas of Alexandria. Egypt J Environ Prot 3: 141- 149

44. Sillen LG (1961) The physical Chemistry of Seawater. Publ. Amer. Ass. Adv Sci. 67 Lectures in the International Oceanographic Congress in New York. pp: $549-581$.

45. Strickland HD, Parsons TR (1972) A practical handbook of seawater analysis Fish Res. Bd Canada Bull. 157: 310.

46. Tayel FTR, Fahamy MA, Shriadah MMA (1996) Studies on the physicochemical characteristics of Max Bay and New Dekhalila Harbor waters of Alexandria. Egypt Bull Nat Inst Oceanogr Fish 22: 1-18.

47. Wahby SD, Shreadah MA (1984) The effect of sewage discharge on some chemical characteristics of seawater. VII Journees Etud Pollutions. Lvcerene CIESM, pp: 81-90. 
Citation: Saad AS, Massoud MA, Amer RA, Ghorab MA (2017) Assessment of the Physico-chemical Characteristics and Water Quality Analysis of Mariout Lake, Southern of Alexandria, Egypt. J Environ Anal Toxicol 7: 421. doi: 10.4172/2161-0525.1000421

Page 19 of 19

48. WHO (1973) Health Hazards of The Human Environment, Geneva. Switzerland, pp: $329-387$.

49. UNEP (1988) (Athena) The 1988 state-of-the-environment report "The public and environment", pp: 23-27.
50. UNESCO, FAO, UNEP (1988) Eutrophication in the Mediterranean Sea MAP Technical report series NO 106 UNEP Athens.

51. Zakaria HY, Radwan AA, Said MA (2007) Influence of salinity variations on zooplankton community in El-Mex Bay, Alexandria. Egypt J Aquat Res 33: 52-67. 